\title{
5. MAGNETOSTRATIGRAPHY OF PLIOCENE-PLEISTOCENE SEDIMENTS FROM THE EASTERN MEDITERRANEAN SEA ${ }^{1}$
}

\author{
Carl Richter, ${ }^{2}$ Andrew P. Roberts, ${ }^{3}$ Joseph S. Stoner ${ }^{4,6}$ L. David Benning, ${ }^{5}$ and Cung T. Chi ${ }^{2,7}$
}

\begin{abstract}
Detailed paleomagnetic investigations were conducted to develop a magnetostratigraphic framework for sedimentary sequences that were recovered by hydraulic piston coring in the Eastern Mediterranean Sea (Ocean Drilling Program Leg 160). A total of 1556 discrete samples from seven sites were subjected to detailed demagnetization, and high-resolution measurements of the magnetic properties of $>100 \mathrm{~m}$ of sediments were made using "U-channel" samples (measurements at 1-cm intervals). The main magnetic carriers are probably an iron sulfide mineral and magnetite; occasional hematite were also present. Between $10 \%$ and $50 \%$ of the samples displayed erratic magnetic behavior and could not be used for magnetostratigraphic analysis. In addition, between $5 \%$ and $49 \%$ of the samples were completely overprinted by the coring process and had significantly higher paleomagnetic inclinations $\left(>75^{\circ}\right.$ ) than would be expected for an axial dipole field (inclinations of $49^{\circ}-52^{\circ}$ ) at the site latitudes. Despite the coring-induced remagnetization and problems with the stability of magnetization, a sound magnetostratigraphic chronology was established at some sites. This chronology provides support for stratigraphic correlations within the basin and with onshore sequences as well as a temporal framework for paleoenvironmental studies that will enable assessment of the origin of organic-rich sapropel layers frequently found in the Mediterranean Sea and adjacent onshore sequences.
\end{abstract}

\section{INTRODUCTION}

Over $7000 \mathrm{~m}$ of uppermost Miocene to Holocene sediments were recovered by coring in the Mediterranean Sea during Ocean Drilling Program (ODP) Legs 160 and 161. The Mediterranean Sea is a semienclosed basin with restricted water exchange with the open ocean. Mediterranean sediments are especially sensitive to climate change, and environmental signals are preserved in great detail. The cored sites reach from the Alboran Sea in the west, through the Tyrrhenian Sea, the Strait of Sicily, the Levantine Basin, the Mediterranean Ridge, to the eastern side of Eratosthenes Seamount, south of Cyprus. Dark, organic-rich, sapropel layers are commonly found in sediments of the Eastern Mediterranean basin and in tectonically uplifted Pliocene and Pleistocene marine sequences that crop out in southern Italy (Calabria), Sicily, and Crete. The discovery of numerous sapropel layers in the westernmost Mediterranean was an important paleoceanographic result of Mediterranean drilling (Comas, Zahn, Klaus, et al., 1996). Organic-rich sediments (often $>2 \%$ total organic carbon) in the Mediterranean Sea were deposited in response to dramatic changes of climate, circulation, and biogeochemical cycling. Sapropels occur in distinct clusters that were interpreted to represent minima in precessional cycles (individual sapropels) and maxima in eccentricity cycles (sapropel clusters; Hilgen, 1987, 1991a) and are much better correlated to insolation than to precession alone (Lourens et al., 1996). The interpretation that individual sapropels coincide with precessional minima is supported by oxygen isotopic age calibration of the most recently deposited upper Pleistocene Mediterranean sapropels (Vergnaud-Grazzini et al., 1977; Rossignol-Strick,

${ }^{1}$ Robertson, A.H.F., Emeis, K.-C., Richter, C., and Camerlenghi, A. (Eds.), 1998. Proc. ODP, Sci. Results, 160: College Station, TX (Ocean Drilling Program).

${ }^{2}$ Ocean Drilling Program and Department of Geology and Geophysics, Texas A\&M University, College Station, TX 77845, U.S.A. richter@tamu.edu

${ }^{3}$ Department of Oceanography, University of Southampton, Southampton Oceanography Centre, Southampton SO14 3ZH, United Kingdom.

${ }^{4}$ Department of Geology, University of Florida, Gainesville, FL 32611, U.S.A

${ }^{5}$ Department of Geology, University of California, Davis, CA 95616, U.S.A.

${ }^{6}$ Present address: Department of Geology, University of California, Davis, CA 95616, U.S.A.

${ }^{7}$ Present address: Department of Geology, National Taiwan University, Taipei, Taiwan.
1983). Older sapropel-bearing sequences have therefore been dated, relative to the appropriate magnetostratigraphic polarity reversal boundaries, by comparing the positions of sapropels to the precisely calculated astronomical solutions of Berger and Loutre (1991).

The Mediterranean sapropels have become important in geochronology because, if the assumption concerning the relationship between astronomical cycles and sapropels is correct, the geomagnetic polarity time scale can be calibrated by counting the number of precessional cycles between reversals (e.g., Hilgen, 1991a, 1991b; Hilgen et al., 1993). Revised age estimates for polarity boundaries, based on astronomical calibration of sapropel-bearing sequences, have become widely accepted and have now been incorporated in the standard geomagnetic polarity time scale, which is primarily based on marine magnetic anomaly records (Cande and Kent, 1995).

Coring in the Mediterranean Sea during Legs 160 and 161 was aimed at recovering stratigraphically complete records that contain pristine sapropels to determine the driving forces behind sapropel formation and to investigate their paleoclimatic and paleoceanographic significance. Previous piston coring of deep-sea sequences in the Mediterranean basin was mainly conducted only to shallow depths: deep coring was restricted to sites from ODP Leg 107 in the Tyrrhenian Sea (Kastens, Mascle, et al., 1990). The Leg 107 magnetostratigraphies were almost entirely based on rotary cores and highquality results were difficult to obtain (Channell et al., 1990; Channell and Torrii, 1990). The success of many of the objectives of Legs 160 and 161, including the potential for testing the accuracy of astronomical calibrations of the geomagnetic polarity time scale, comparison of deep-sea sequences with onshore sequences, and understanding links between the eastern and western Mediterranean basins, depends upon obtaining a precise chronostratigraphic framework.

Shipboard paleomagnetic measurements during Leg 160 encountered numerous problems, including (Roberts et al., 1996) coringinduced remagnetizations; long-core measurement artifacts that result from stratigraphically restricted changes in remanence intensity in the vicinity of sapropels (Roberts et al., in press); and the inability to assess the stability of the sediment magnetization because of time constraints imposed by rapid core recovery, which prevented longcore measurements at more than a single demagnetization level. Because of these problems, reliable long-core data were not obtained on board ship. Despite this, shipboard demagnetization of discrete sam-

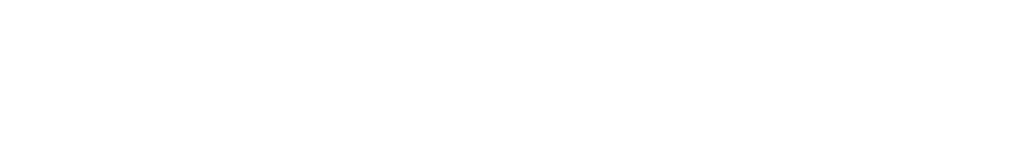


ples (from the working halves of the cores) indicated that the sediments are usually relatively stably magnetized and that further shorebased work might help elucidate the magnetic polarity history of these sediments. In this paper, we describe detailed shore-based studies that were aimed at deriving magnetostratigraphic chronologies for the sediments recovered at each site occupied during Leg 160 to the Eastern Mediterranean Sea (Fig. 1).

\section{SAMPLING AND EXPERIMENTAL PROCEDURES Depth Scales}

Coring of multiple advanced piston coring system (APC) holes, which were offset in depth, ensured that intervals of no recovery from a single APC hole were recovered in adjacent holes at each site. To enable and facilitate comparisons among holes at a given site, we express depth not only on the standard ODP $\mathrm{m}$ below seafloor (mbsf) scale, but also on the m composite depth (mcd) scale, which was established by intercore correlation procedures (Hagelberg et al., 1992) during Leg 160 (Emeis, Robertson, Richter, et al., 1996), and on the revised mcd (rmcd) scale that was established during detailed postcruise work (Sakamoto et al., Chap. 4, this volume). In this study, we have dominantly used the rmcd scale. Conversions between the three depth scales are straightforward (Sakamoto et al., Chap. 4, this volume).

\section{Samples}

To ensure complete stratigraphic recovery, post-cruise sampling was generally conducted along the composite spliced sections that were constructed during Leg 160. The composite sequence comprises material from different holes and was constructed to avoid coring gaps and disturbances. Three discrete samples were taken from each 1.5-m section from undemagnetized working halves from Sites 963, 964, 966, 967, 968, 969, 972, and 973. Intervals of gray sediment were avoided during sampling because shipboard measurements indicated that such intervals were weakly and unstably magnetized, probably because of diagenetic dissolution of magnetic minerals in these intervals (e.g., Karlin and Levi, 1983, 1985; Canfield and Berner, 1987; Channell and Hawthorne, 1990; Dekkers et al., 1994; Roberts et al., 1996). Paleomagnetic samples were obtained by pushing plastic boxes $\left(7 \mathrm{~cm}^{3}\right)$ into the working half of a core (with an arrow indicating the "up" direction) and then by removing the box using a nonmagnetic sample extraction tool.

Before thermal demagnetization, samples were dried in zero magnetic field, removed from the plastic box, and wrapped in aluminum foil (the aluminum foil was measured in the cryogenic magnetometer and was found to have no measurable remanent magnetization). The orientation and the sample number were carefully inscribed on each sample.

In addition, U-channel samples (U-shaped, 2- $\mathrm{cm}^{2}$ cross-section plastic channels, up to $1.5 \mathrm{~m}$ in length) were taken from the archive halves of the composite sequence to make continuous long-core paleomagnetic and mineral magnetic measurements, as described by Weeks et al. (1993). Most of the sections from which U-channel samples were taken had been demagnetized at 20 or $25 \mathrm{mT}$ on the ship and were subsequently demagnetized at 20 (25), 30, 40, 50, 60, and $70 \mathrm{mT}$ before being given an anhysteretic remanent magnetization (ARM) and an isothermal remanent magnetization (IRM; Stoner et al., Chap. 6, this volume).

\section{Measurements}

Paleomagnetic measurements were made aboard the JOIDES Resolution, predominantly on archive-half sections using a 2-G Enterprises (model 760R) pass-through superconducting rock magne-

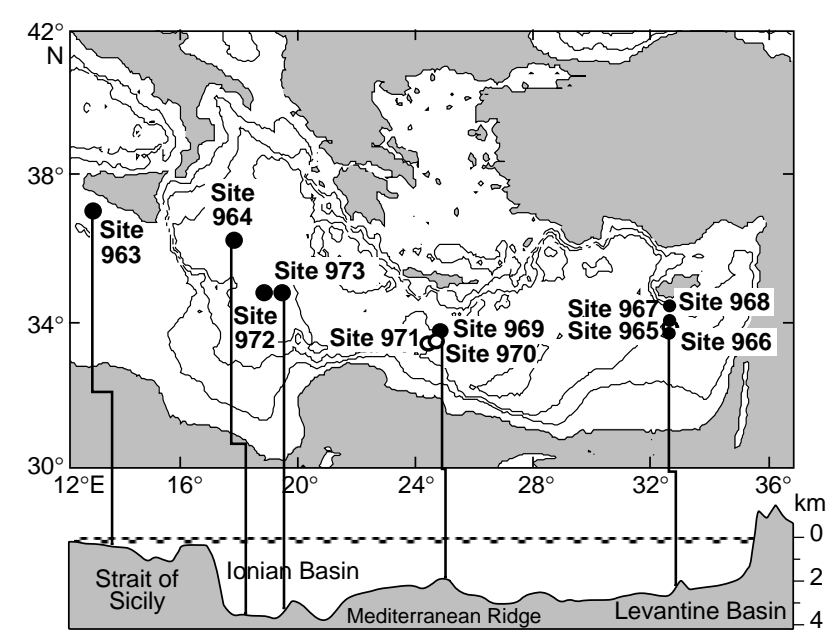

Figure 1. Map and bathymetric cross section of the Mediterranean Sea with locations of sites from which cores were recovered during Leg 160. Solid circles $($ open circles $)=$ sites addressed (not addressed) in this study.

tometer. Pass-through paleomagnetic measurements were made on the archive halves of all APC sections for every hole at each site. We measured the natural remanent magnetization (NRM) at $10-\mathrm{cm}$ intervals after alternating-field (AF) demagnetization at either 20 or 25 $\mathrm{mT}$. The pass-through measurements were supplemented by measurements of discrete samples that were made using a Molspin spinner magnetometer.

Shore-based paleomagnetic studies were carried out on discrete samples using cryogenic magnetometers at the paleomagnetic laboratories of the University of California at Davis (UCD) for Sites 963, 964, 972, and 973; University of Florida (UF) for Sites 966, 968, and 969; and Texas A\&M University (TAMU) for Site 967. Each sample was subjected to either AF demagnetization (using a Schonstedt Instrument Co., Model GSD-1 AC Geophysical Specimen Demagnetizer) or to thermal demagnetization (using a Schonstedt Instrument Co., Model TSD-1 Thermal Specimen Demagnetizer). Magnetic susceptibilities were measured using a Bartington Instruments MS-2 Magnetic Susceptibility meter to monitor for thermochemical alteration in samples that were subjected to thermal demagnetization. Measurements were made at room temperature and after each heating cycle $\left(25^{\circ}-100^{\circ} \mathrm{C}\right.$ steps between $20^{\circ}$ and $\left.650^{\circ} \mathrm{C}\right)$. After measuring the natural remanent magnetization (NRM), AF demagnetization was conducted at $5,10,15,20,30,40,50$, and $60 \mathrm{mT}$ (UCD).

U-channel samples were all measured at the UCD paleomagnetic laboratory on a pass-through cryogenic magnetometer (2-G Enterprises model 750R) at $1-\mathrm{cm}$ intervals. The magnetometer is equipped to impart an ARM and an IRM at various fields. All data (NRM, ARM, IRM, susceptibility) are presented in an accompanying paper by Stoner et al. (Chap. 6, this volume) and can be retrieved from the Leg 160 CD-ROM. Because the depth for each U-channel measurement is controlled to within $1 \mathrm{~mm}$ on the sample track (by a computer-controlled microswitch), the demagnetization characteristics of Uchannel samples can be assessed by constructing vector-component plots at regular intervals (usually $1 \mathrm{~cm}$ ).

Volume magnetic susceptibility was measured at 3- to 5-cm intervals aboard the JOIDES Resolution on whole-core sections using a Bartington Instruments MS-2 susceptibility meter. This instrument has an 80-mm-diameter sensing loop that induces a 0.1 -mT field at a frequency of $470 \mathrm{~Hz}$. Matching of shipboard susceptibility measurements with the $1-\mathrm{cm}$ resolution of the shore-based measurements was achieved by linear regression between the respective measurements using AnalySeries software (Paillard, 1996). 


\section{Reliability of Demagnetization Behavior}

Reliability of the demagnetization data was determined by inspection of vector-component plots and intensity-decay curves (Fig. 2). Each sample was ranked on an arbitrary scale of "A," "B," or "C." A sample was given an "A" ranking if there was an obvious, uniformly stable direction that was clearly identifiable over multiple demagnetization levels (Fig. 2A). The best-fit linear regression line for such samples typically has a low maximum angular deviation $\left(\mathrm{MAD}<5^{\circ}\right.$ ).

"B" rankings were given to samples that were less stably magnetized than category "A" samples, but that still gave a relatively clear indication of primary polarity (e.g., Fig. 2B). Directional scatter during demagnetization was usually relatively high for such samples $\left(\mathrm{MAD} \approx 5^{\circ}\right.$ ). Relatively few samples displayed type "B" behavior.

Nearly all secondary overprints have normal polarity that is caused by coring-induced effects, or by the normal-polarity Brunhes
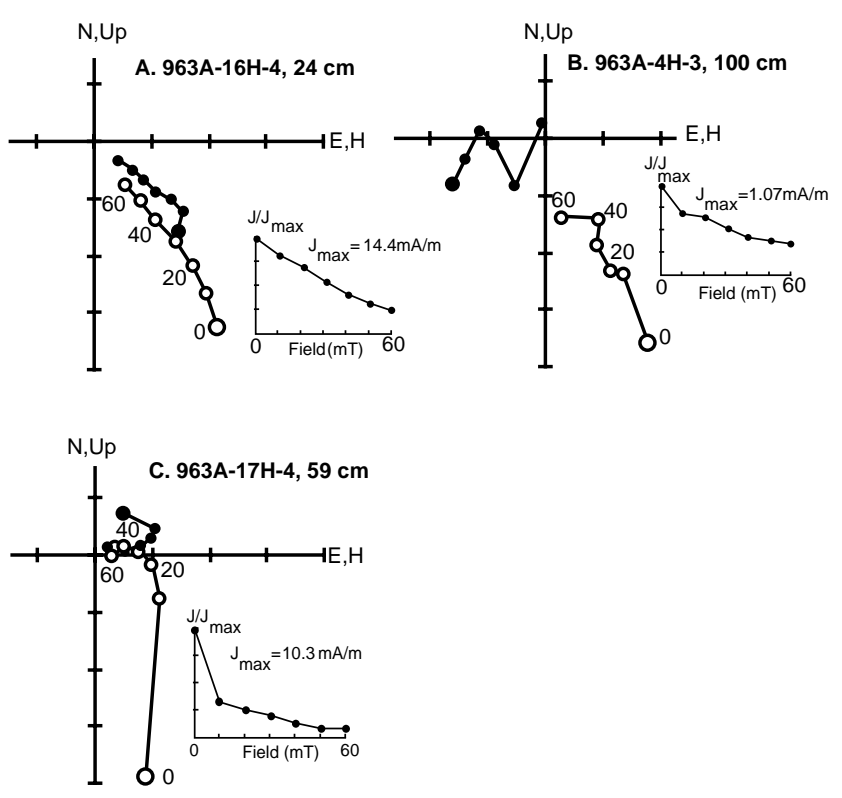

Figure 2. Examples of different types of demagnetization behavior that were used to classify samples in this study. A. Type "A" samples display a stable remanence component across multiple demagnetization steps (from Sample 160-963A-16H-4, $24 \mathrm{~cm}$ ). B. Type "B" samples (from Sample 160-963A$4 \mathrm{H}-3,100 \mathrm{~cm}$ ) display somewhat irregular demagnetization behavior. The sample was probably magnetized in a normal polarity (Brunhes chron) field, but was not included in the final magnetostratigraphic analysis because of the irregularity of the demagnetization trajectory. C. Type "B" sample that displays regular demagnetization behavior, with a significant coring-induced overprint from Sample 160-963A-17H-4, $59 \mathrm{~cm}$. The characteristic component is probably of reversed polarity, but is obscured by the overprint. Open (solid) symbols indicate projections onto the vertical (horizontal) plane.
Chron geomagnetic field. Because strong overprinting always biased results toward normal polarity, slightly more weight was given to a sample that displayed poorly resolved reversed polarity behavior (e.g., Fig. 2C). Because samples that had a positive inclination near $75^{\circ}-90^{\circ}$ usually had a low MAD (often $\sim 1^{\circ}$ ), they were included in category " $A$ " but were left out of the final analysis because they were probably remagnetized by coring-induced effects. Because the latitude of the Mediterranean Sea is relatively low (about $40^{\circ} \mathrm{N}$ ), it is not difficult to distinguish between a remanence of detrital origin and the steep normal-polarity directions that result from coring-induced remagnetizations.

Finally, if a sample displayed no obvious characteristic remanence component, it was given a " $\mathrm{C}$ " ranking. This category usually included samples that were either weakly magnetized or erratically behaved. No interpretation was attempted for such samples.

For the final magnetostratigraphic interpretation, only samples with an " $A$ " ranking were retained. All samples with "B" and " $C$ " rankings were omitted, as were samples that were dominated by obvious coring-induced overprints. The above demagnetization and data interpretation procedures were routinely used to derive a magnetostratigraphy for Sites 963, 964, 966, 967, 968, 969, 972, and 973, as discussed below. Dates for the magnetic polarity boundaries are based on those of Cande and Kent (1995) and the biostratigraphy is based on the Mediterranean chronology of Sprovieri (1993).

\section{RESULTS Site 963}

Site 963 is located in the Strait of Sicily (Fig. 1), at a water depth of about $470 \mathrm{~m}$, between Adventure Bank and Gela Basin, on the unstable foreland of the African Plate. Site 963 was selected using commercial multichannel seismic surveys from the southern edge of Sicily and was placed in the Strait of Sicily to monitor changes in circulation between the eastern and western sub-basins of the Mediterranean Sea. This site was also cored to supplement the highresolution stratigraphy obtained from the adjacent onshore sequence at Capo Rosello, Sicily (Langereis and Hilgen, 1991) by providing a record that extends from the early Pleistocene to the Holocene.

The 207-m sequence recovered from Site 963 is dominated by relatively homogenous, calcareous, olive-green, nannofossil clays, with minor quartzose silt and volcanic glass (Emeis, Robertson, Richter, et al., 1996). No distinct sapropel horizons were documented, and no marked downcore changes in lithology were present. Sedimentation rates at Site 963 are relatively high ( $\sim 21 \mathrm{~cm} / \mathrm{k} . \mathrm{y}$.), largely because of mass wasting associated with thrust loading on Sicily (Emeis, Robertson, Richter, et al., 1996).

Paleomagnetic sampling was restricted to Hole 963A, which provided the clearest and most detailed magnetostratigraphy of the sites occupied during Leg 160. A total of 242 discrete samples from Hole 963A were subjected to stepwise AF demagnetization (Table 1). Vector-demagnetization diagrams (e.g., Fig. 2) indicate the removal

Table 1. Reliability of demagnetization behavior.

\begin{tabular}{rrrrrrrrrrr}
\hline Site & N & D/U & A & A $~$ & B & B $~$ & C & C\% & DR & DR \\
\hline 963 & 242 & D & 207 & 86 & 9 & 4 & 13 & 5 & 13 & 5 \\
964 & 278 & D & 152 & 55 & 40 & 14 & 15 & 5 & 71 & 26 \\
966 & 177 & D & 56 & 32 & 31 & 17 & 64 & 36 & 26 & 15 \\
967 & 308 & D & 124 & 40 & 23 & 8 & 40 & 13 & 121 & 39 \\
967 & 5472 & U & 3942 & 72 & 0 & 0 & 1182 & 22 & 348 & 6 \\
968 & 54 & D & 7 & 13 & 0 & 0 & 20 & 37 & 27 & 50 \\
969 & 239 & D & 126 & 53 & 0 & 0 & 73 & 30 & 40 & 17 \\
972 & 109 & D & 84 & 78 & 17 & 16 & 0 & 0 & 7 & 6 \\
973 & 126 & D & 100 & 79 & 12 & 10 & 3 & 2 & 11 & 9 \\
\hline
\end{tabular}

Note: $\mathrm{N}=$ number of samples; $\mathrm{D}=$ discrete; $\mathrm{U}=\mathrm{U}$-channel; $\mathrm{A}=$ stable; $\mathrm{B}=$ clear primary polarity; $\mathrm{C}=$ unstable; $\mathrm{DR}=$ drill string remagnetization. 
Table 2. Summary of magnetostratigraphic datum levels.

\begin{tabular}{|c|c|c|c|c|c|c|c|c|c|c|c|}
\hline Site & & ronozone & & $\begin{array}{l}\text { CK95 } \\
\text { (Ma) }\end{array}$ & Hole & Core & Section & $\begin{array}{l}\text { Interval } \\
(\mathrm{cm})\end{array}$ & $\begin{array}{l}\text { Depth } \\
\text { (mbsf) }\end{array}$ & $\begin{array}{l}\text { Depth } \\
\text { (mcd) }\end{array}$ & $\begin{array}{l}\text { Depth } \\
\text { (rmcd) }\end{array}$ \\
\hline 963 & $\begin{array}{l}\text { C1n } \\
\text { C1r.1n } \\
\text { C1r.1n } \\
\text { C1r.2r-1n }\end{array}$ & $\begin{array}{l}\text { Brunhes } \\
\text { Jaramillo } \\
\text { Jaramillo } \\
\text { Cobb Mountain }\end{array}$ & $\begin{array}{c}\mathrm{o} \\
\mathrm{t} \\
\mathrm{o} \\
\mathrm{o} / \mathrm{t}\end{array}$ & $\begin{array}{l}0.780 \\
0.990 \\
1.070 \\
1.211\end{array}$ & $\begin{array}{l}963 \mathrm{~A} \\
963 \mathrm{~A} \\
963 \mathrm{~A} \\
963 \mathrm{~A}\end{array}$ & $\begin{array}{l}17 \mathrm{H} \\
19 \mathrm{H} \\
21 \mathrm{H} \\
23 \mathrm{H}\end{array}$ & $\begin{array}{l}2 \\
4 \\
4 \\
4\end{array}$ & $\begin{array}{r}105 \\
137 \\
95 \\
66\end{array}$ & $\begin{array}{l}145.65 \\
161.96 \\
175.85 \\
191.16\end{array}$ & $\begin{array}{l}149.46 \\
165.37 \\
179.66 \\
195.48\end{array}$ & $\begin{array}{l}\bar{z} \\
\bar{z}\end{array}$ \\
\hline 964 & $\mathrm{C} \ln (?)$ & Brunhes(?) & o & 0.780 & $964 \mathrm{D}$ & $4 \mathrm{H}$ & 2 & 84 & 25.44 & 27.00 & 30.88 \\
\hline 966 & $\begin{array}{l}\text { C2n } \\
\text { C2n } \\
\text { C2r.1n } \\
\text { C2r.1n } \\
\text { C2An.1n } \\
\text { C2An.1r } \\
\text { C2An.1r }\end{array}$ & $\begin{array}{l}\text { Olduvai } \\
\text { Olduvai } \\
\text { Reunion } \\
\text { Reunion } \\
\text { Gauss } \\
\text { Kaena } \\
\text { Kaena }\end{array}$ & $\begin{array}{l}\mathrm{t} \\
\mathrm{o} \\
\mathrm{t} \\
\mathrm{o} \\
\mathrm{t} \\
\mathrm{t} \\
\mathrm{o}\end{array}$ & $\begin{array}{l}1.770 \\
1.950 \\
2.140 \\
2.150 \\
2.581 \\
3.040 \\
3.110\end{array}$ & $\begin{array}{c}966 \mathrm{~B} \\
966 \mathrm{~B} \\
966 \mathrm{~B} \\
966 \mathrm{~B} \\
966 \mathrm{D} \\
966 \mathrm{C} \\
966 \mathrm{~B}\end{array}$ & $\begin{array}{l}4 \mathrm{H} \\
4 \mathrm{H} \\
4 \mathrm{H} \\
4 \mathrm{H} \\
5 \mathrm{H} \\
5 \mathrm{H} \\
6 \mathrm{H}\end{array}$ & $\begin{array}{l}2 \\
4 \\
6 \\
6 \\
3 \\
5 \\
1\end{array}$ & $\begin{array}{r}98 \\
37 \\
41 \\
131 \\
100 \\
63 \\
113\end{array}$ & $\begin{array}{l}29.17 \\
31.53 \\
34.57 \\
35.49 \\
35.99 \\
44.64 \\
46.83\end{array}$ & $\begin{array}{l}29.73 \\
32.09 \\
35.13 \\
36.05 \\
38.86 \\
46.53 \\
48.42\end{array}$ & $\begin{array}{l}30.78 \\
33.01 \\
36.07 \\
36.99 \\
39.95 \\
46.49 \\
49.05\end{array}$ \\
\hline 967 & $\begin{array}{l}\text { Cln } \\
\text { Clr. } 1 n\end{array}$ & $\begin{array}{l}\text { Brunhes } \\
\text { Jaramillo }\end{array}$ & $\begin{array}{l}o \\
t\end{array}$ & $\begin{array}{l}0.780 \\
0.990\end{array}$ & $\begin{array}{l}967 \mathrm{~A} \\
967 \mathrm{~A}\end{array}$ & $\begin{array}{l}4 \mathrm{H} \\
4 \mathrm{H}\end{array}$ & $\begin{array}{l}1 \\
4\end{array}$ & $\begin{array}{l}48 \\
98\end{array}$ & $\begin{array}{l}29.08 \\
33.78\end{array}$ & $\begin{array}{l}30.96 \\
35.66\end{array}$ & $\begin{array}{l}30.60 \\
35.22\end{array}$ \\
\hline
\end{tabular}

Notes: CK95 $=$ Cande and Kent (1995). $\mathrm{o}=$ onset; $\mathrm{t}=$ termination. A revised meters composite depth scale for Site 963 does not exist.

of a low-coercivity magnetic overprint in fields $<20 \mathrm{mT}$, followed by the isolation of a stable characteristic component.

\section{Magnetostratigraphic Interpretation}

Lower quality data (categories "B," "C," and remagnetized samples, Table 1) were not included in the final interpretation (35 samples). The Matuyama/Brunhes boundary is interpreted to lie at about 145.7 mbsf (Table 2), and the Jaramillo subchron lies between 162 and 176 mbsf. In addition, the Cobb Mountain cryptochron is tentatively identified at $191 \mathrm{mbsf}$ (Fig. 3).

Biostratigraphic results were obtained from Hole 963B and were correlated with Hole 963A using the interhole correlation technique described above. Calcareous nannofossil events in Hole 963B (Di Stefano, Chap. 8, this volume) provide firm age constraints through correlation with the well-defined chronostratigraphic scheme for the Mediterranean (Sprovieri, 1993). The magnetostratigraphy provides excellent support for the calcareous nannofossil data (Fig. 4), which together indicate that Site 963 contains a continuous record to 1.5 Ma.

Elucidation of the magnetic polarity stratigraphy was the primary aim of our studies at Site 963, and measurements that were made within the Brunhes Chron were not of sufficient density to enable clear identification of any short geomagnetic excursions. Further studies, in progress, are designed to obtain a detailed record of geomagnetic field behavior within the Brunhes Chron at Site 963.

\section{Site 964}

Site 964 appears to lie at the toe of the Calabrian accretionary wedge (Fig. 1), on top of the Pisano Plateau, at a water depth of 3657 m. The floor of the Ionian Abyssal Plain, which lies at depths of greater than $3800 \mathrm{~m}$, is underthrust beneath the Calabrian Arc (Finetti, 1982). The sediments that comprise the Southern Calabrian Ridge are of late Pliocene, Pleistocene, and Holocene age (Blechschmidt et al., 1982).

Six holes were cored at Site 964 (Holes 964A-964F) to derive an early Pliocene to Holocene composite record. The color of the sediments varies markedly with depth. Many of the variations in color are strongly influenced by cyclic variations in early diagenetic conditions, which are dominantly controlled by organic matter diagenesis associated with the presence of sapropels (Calvert, 1983; Sutherland et al., 1984; Klinkhammer and Lambert, 1989). A continuously overlapping sequence was recovered from six holes to a depth of about 105 mcd.

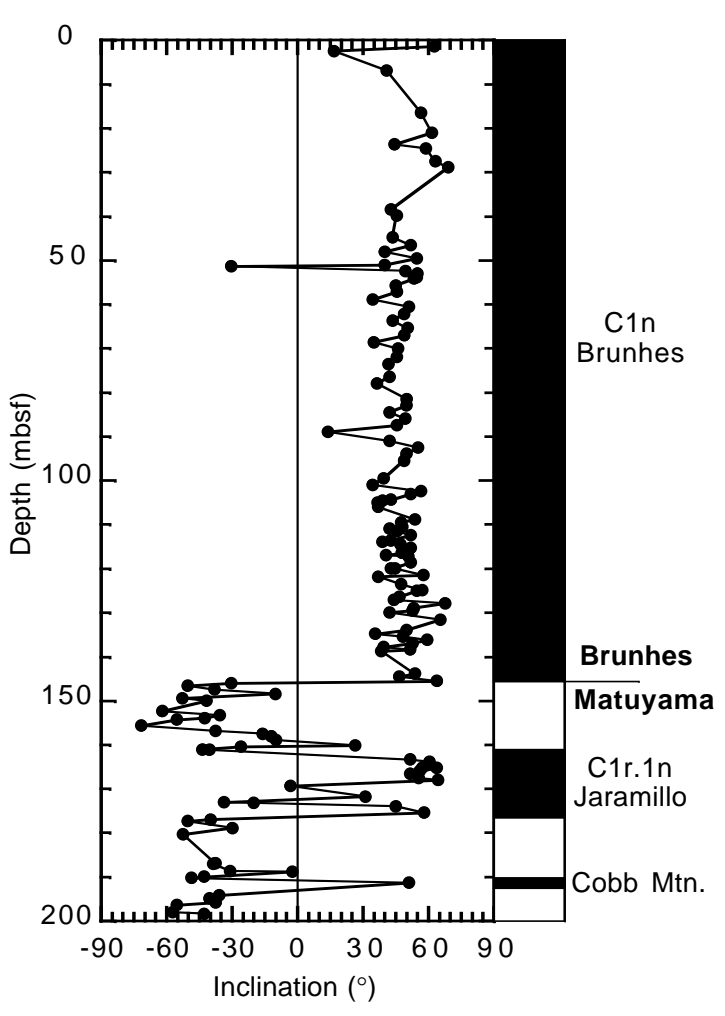

Figure 3. Paleomagnetic data and magnetostratigraphic interpretation for all stably magnetized samples from Site 963. Tentative interpretation of the Cobb Mountain cryptochron is based on only one data point. Black (white) $=$ normal (reversed) polarity.

\section{Results from the Pilot Study}

Twenty samples were selected to determine whether AF or thermal demagnetization would be the best procedure for routine demagnetization. These samples represented a nearly complete range of colors found among the sample collection. The samples were cut in half using a demagnetized razor blade and were allowed to dry in a zerofield environment for 2 days.

Comparison of the NRM direction of the original sample with those of the two subsamples indicated that dividing the sample did 


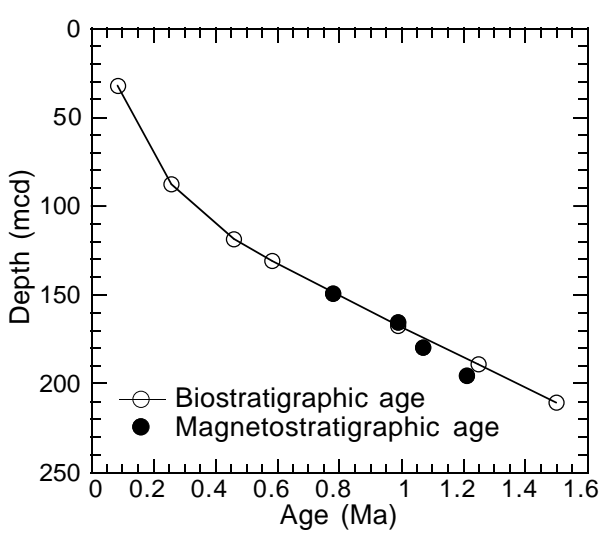

Figure 4. Comparison between biostratigraphic age determinations (Di Stefano, Chap. 8, this volume) and the magnetostratigraphic interpretation at Site 963. The magnetostratigraphic interpretation provides clear independent support for the biostratigraphic interpretation.

not significantly disturb the remanence direction. There was also generally a high degree of similarity between the directions isolated by AF and thermal demagnetizations. A representative pair of vectorcomponent plots is presented in Figure 5. Both subsamples from Sample 160-964B-10H-3, 119 cm, displayed a marked normal polarity secondary overprint (which might have been induced by coring effects) that was superimposed on a reversed polarity characteristic direction.

Agreement between the two demagnetization methods appears to be independent of lithology and sediment color. Even in highly oxidized red sediments (such as the example in Fig. 5) secondary overprints were removed as effectively by $\mathrm{AF}$ as by thermal demagnetization. Because AF demagnetization was usually as successful in removing secondary overprints as thermal demagnetization (even in the red sediments where hematite might be suspected to be present in significant amounts), and because comparable characteristic remanence components were identified by the two methods, AF demagnetization was used routinely for studies of Sites 963, 964, 972, and 973, and for the demagnetization of U-channel samples.

A total of 278 discrete samples from Site 964 were subjected to stepwise demagnetization. Thirty-two samples were subjected to thermal demagnetization, 20 of which were split in half for the pilot study described above (these subsamples were subjected to AF and thermal demagnetization, respectively). Of the 278 demagnetized samples, only 152 were classified in category " $A$ " and were retained for final analysis (Table 1). Examples of vector-demagnetization diagrams of normal and reversed polarity samples are shown in Figure 6. A low-coercivity, coring-induced remanence component is generally removed in fields of $<10 \mathrm{mT}$ (Fig. 6A), although fields of $30 \mathrm{mT}$ are sometimes required to isolate a stable remanence component (Fig. 6B). These samples were apparently not completely remagnetized by coring; that is, the characteristic remanence is represented by a stable, well-defined direction with inclination $<75^{\circ}$. The degree of overprinting by secondary fields is variable, and some samples are apparently completely remagnetized by coring-induced effects (Fig. $6 C)$.

\section{Magnetostratigraphic Interpretation}

From a comparison of the stratigraphic positions of biostratigraphic datums (Sprovieri et al., Chap. 12, this volume) with the magnetic polarity (Fig. 7), it is apparent that no systematic polarity pattern is preserved below $30 \mathrm{mcd}$. The lack of an interpretable magnetostratigraphy is partially caused by the large-scale remagnetization

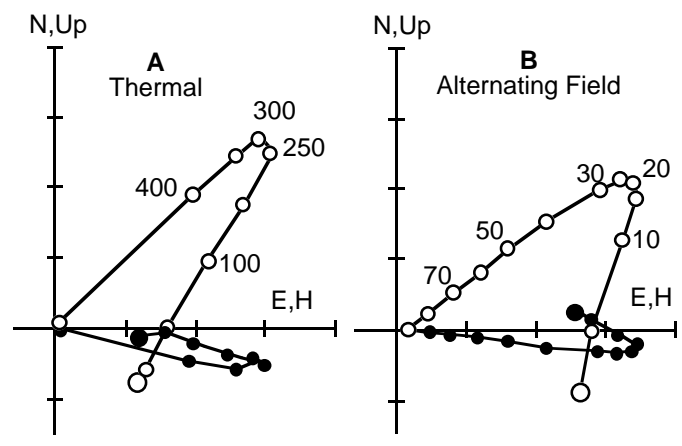

Figure 5. Example of results from the pilot study for a sample from Site 964. Vector-component diagrams from (A) thermal demagnetization, and (B) AF demagnetization of subsamples from Sample 160-964B-10H-3, $119 \mathrm{~cm}$. Symbols are as in Figure 2.
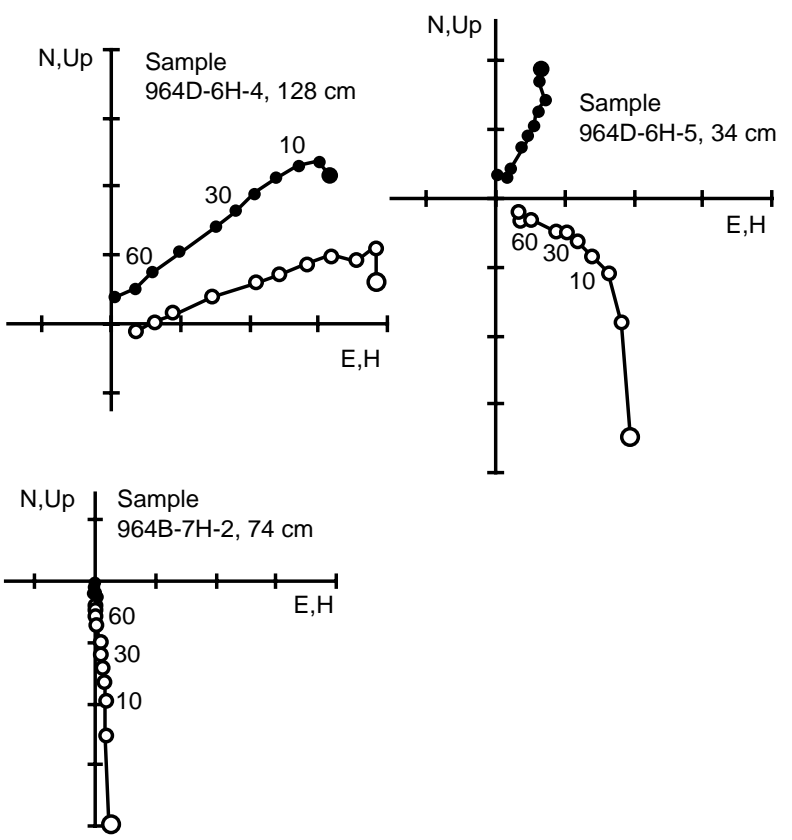

Figure 6. Vector-component diagrams for representative discrete samples with reversed and normal polarity from Site 964 (AF demagnetization). The steep, low-coercivity, coring-induced overprint is removed in AFs <20 mT. Demagnetization steps (in $\mathrm{mT}$ ) are indicated on the figure. Symbols are as in Figure 2.

that occurred at this site, especially in the lowermost cores (samples with steep inclinations that were affected by coring-induced remagnetizations are retained in Fig. 7). The paleomagnetic polarity pattern in the upper part of the record is a sufficiently coherent to allow identification of a polarity reversal (R-N) that presumably represents the Matuyama/Brunhes boundary at $\sim 27 \mathrm{mcd}$ (Table 2 ). Based on the biostratigraphic results, however, this depth corresponds to an age of $\sim 0.9 \mathrm{Ma}$, which is $\sim 0.12 \mathrm{~m}$.y. older than would be expected if the R$\mathrm{N}$ polarity reversal represents the Matuyama/Brunhes boundary.

Extensive faulting was observed in the cores recovered from Site 964 , which is consistent with what might be expected from a site that was cored on the toe of an accretionary wedge (Emeis, Robertson, Richter, et al., 1996). In particular, the color reflectance data, from which the composite sequence was derived, do not display good 


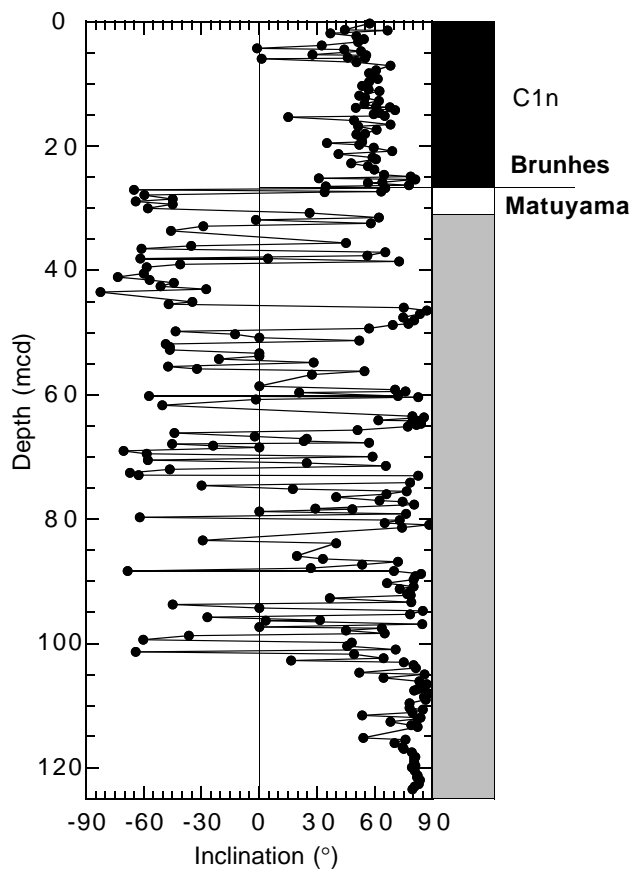

Figure 7. Paleomagnetic data and magnetostratigraphic interpretation for all stably magnetized samples from Site 964 . The Matuyama/Brunhes boundary is tentatively identified at about $27 \mathrm{mcd}$. However, biostratigraphic data indicate that this level is dated at approximately $0.9 \mathrm{Ma}$ (see text for discussion). Data below $30 \mathrm{mbsf}$ are scattered and exhibit no clear magnetostratigraphy. Coring-induced remagnetizations completely dominate the record below 105 mcd.

agreement among cores in the interval from 25.5 to $30 \mathrm{mcd}$, whereas correlation is again possible below 30.5 mcd (Emeis, Robertson, Richter, et al., 1996). The first occurrence of Gephyrocapsa sp. 3 is documented in Sample 160-964A-4H-3, 40-42 cm (29.89 mcd). This occurrence, however, normally lies at about $0.99 \mathrm{Ma}$, during the Jaramillo Subchron (Sprovieri, 1993), which suggests that Jaramilloage sediments from Core 160-964A-4H (at about 26.5-30 mbsf) were juxtaposed against Brunhes-age sediments, with an interval of reversed polarity (C1r) having been faulted out of the record. Such an interpretation would suggest significant structural displacement, possibly along a reverse fault. There is little independent evidence for such a large structural displacement. If correct, however, this observation calls into question the continuity of the composite sequence and the validity of the interpreted composite sequence in the lower parts of the recovered record.

Given the proximity of Site 964 to Core KC01, from which detailed magnetostratigraphic records were obtained (Dekkers et al., 1994), including high-resolution records of inferred geomagnetic excursions (Langereis et al., 1997), the results from Site 964 are disappointing.

\section{Site 966}

The main objectives of coring at Site 966 (Fig. 1) were to recover a complete record of Pliocene-Pleistocene sapropels as an indicator of paleoenvironmental change in the easternmost Mediterranean Sea and to decipher the subsidence history of Eratosthenes Seamount and the age, origin, and nature of the deeper part of the sequence (Miocene and older). Site 966 is located near the northern margin of the plateau area of the Eratosthenes Seamount at a water depth of $926 \mathrm{~m}$. Sedimentation rates vary from 1 to $32 \mathrm{~m} / \mathrm{m}$.y. throughout the recovered sequence. Shipboard magnetostratigraphy enabled the tentative

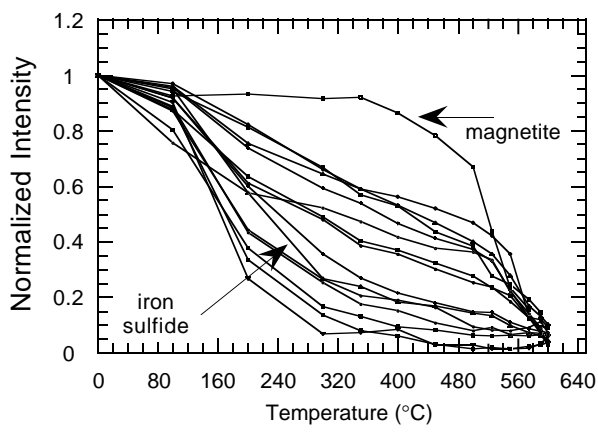

Figure 8. Intensity-decay curves for thermal demagnetization of samples from Site 966. The unblocking temperature spectra are consistent with the presence of magnetite and a magnetic iron sulfide mineral in varying concentrations.

interpretation of magnetic polarity boundaries to $4.5 \mathrm{Ma}$. The reliability of the shipboard paleomagnetic analysis could not be assessed during Leg 160, however, because of time constraints.

Discrete paleomagnetic samples were taken from the $65-\mathrm{m}$ composite sequence of Holes 966A, 966B, 966C, and 966D at 0.5-m intervals. Continuous sampling of U-channels was conducted in the uppermost $60 \mathrm{rmcd}$ and results from the interval between 30 and 60 rmcd are available to date. The sediment is generally a moderately bioturbated, gray nannofossil ooze that is intercalated with numerous sapropels and a few thin ash layers (Emeis, Robertson, Richter, et al., 1996).

\section{Paleomagnetic Results}

A total of 177 discrete samples from Holes 966A to 966D were subjected to stepwise thermal demagnetization. Only 56 were ranked in category "A" and were obviously not remagnetized (Table 1).

Thermal demagnetization of most samples produced a noticeable drop in intensity between $100^{\circ} \mathrm{C}$ and $330^{\circ} \mathrm{C}$ (Fig. 8), which is generally characteristic of ferrimagnetic iron sulfide minerals (e.g., Dekkers, 1989; Roberts, 1995). The presence of magnetic iron sulfide minerals has not been confirmed by unambiguous mineralogical identification, but is strongly suspected based on thermal demagnetization behavior and based on studies of the magnetic properties of sapropels (Roberts et al., in press). The presence of magnetic iron sulfide minerals is likely, given the relatively common occurrence of magnetic sulfides (usually greigite) in other studies of PliocenePleistocene marine sediments from the Mediterranean region (e.g., Garavelli and Nuovo, 1971; Bracci et al., 1985; Albianelli et al., 1993; Van Velzen et al., 1993; Florindo and Sagnotti, 1995; Mattei et al., 1996). Formation of new magnetic material occurred frequently during heating above $350^{\circ} \mathrm{C}$, which prevented determination of characteristic remanence directions at elevated temperatures. For many samples, remanence intensity decreases slightly near $550^{\circ} \mathrm{C}$ (Fig. 8), with little remanent magnetization above the Curie temperature of magnetite $\left(575^{\circ}-585^{\circ} \mathrm{C}\right.$; see Hunt et al., 1995). Few samples contained enough magnetite to dominate the magnetic behavior. A broad range of unblocking temperatures is evident in Figure 8, which may indicate that some samples are dominated by either magnetite or by an iron sulfide mineral, but most samples contain a mixture of both types of mineral.

The presence of high-coercivity minerals such as hematite or goethite was suspected because of the reddish to yellow-red color of many samples. The intensity-decay curves for some of the red samples indicate that a small portion of the remanence persists to above $600^{\circ} \mathrm{C}$ (about $10 \%$ of $J_{\text {max }}$; Fig. 8). This is consistent with the presence of hematite, which has a Néel temperature of $675^{\circ} \mathrm{C}$ (Hunt et al., 1995). Hematite, however, has a weak magnetic moment and does 
not appear to dominate the magnetic signature of even the reddest sediments.

A stable characteristic remanence direction is usually isolated after removal of a low-temperature overprint (Fig. 9). About half of the samples from Site 966 displayed erratic behavior during thermal demagnetization (Fig. 9). The generally low quality of the paleomagnetic data at this site makes it difficult to establish a reliable magnetostratigraphy. Only samples that contain a significant amount of magnetite (Fig. 8) appear to carry a stable magnetization that can be interpreted for magnetostratigaphic purposes.

AF demagnetization of U-channel samples between 30 and 60 mcd provided 3052 data points that provide useful constraints on the magnetostratigraphy. Large parts of this interval are characterized by a well-behaved remanence component, after removal of a low-coercivity, coring-induced overprint by $30 \mathrm{mT}$.

\section{Magnetostratigraphic Interpretation}

Lower quality data (categories "B," "C," and obviously remagnetized samples) were not included in the final magnetostratigraphic interpretation (Fig. 10). Agreement between discrete data and passthrough measurements is generally excellent and, despite the generally poor quality of the discrete sample data, an interpretable magnetic polarity pattern is evident. However, because of uncertainty concerning the reliability of demagnetization data from discrete samples, we did not attempt a magnetostratigraphic interpretation in the parts of the sequence that were not supported by data from U-channel samples.

The Olduvai subchron (C2n) can be identified between 30.78 and $33.01 \mathrm{rmcd}$ (Table 2). C2r.1n (the Réunion subchron) lies between 36.07 and $36.99 \mathrm{rmcd}$, and the Gauss/Matuyama boundary is recorded at $39.95 \mathrm{rmcd}$. The Kaena subchron and the termination of the Mammoth subchron are evident at 46.49 to $49.05 \mathrm{rmcd}$ and at 52.00 rmcd, respectively. Within the Mammoth subchron, scatter of the paleomagnetic inclinations prevents detection of the onset of C2An.3n, which is expected between 56 and $60 \mathrm{rmcd}$, based on biostratigraphic evidence. Such large amounts of scatter in paleomagnetic directions
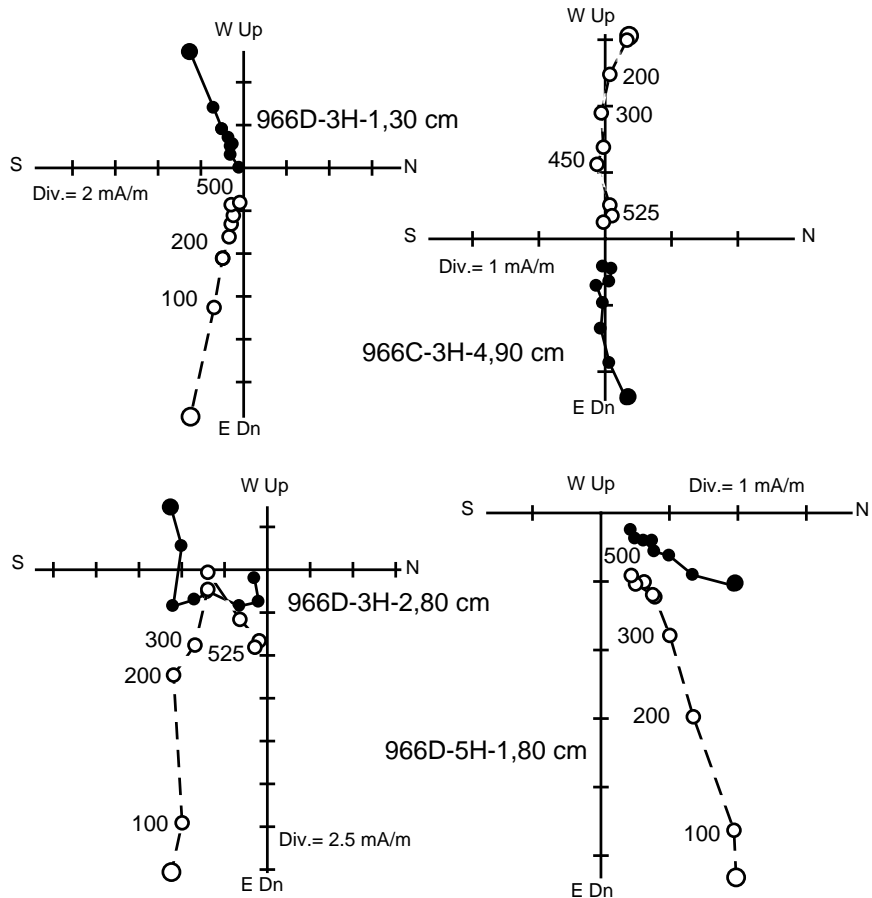

Figure 9. Vector-component diagrams for representative discrete samples with normal and reversed polarity from Site 966 (thermal demagnetization). Typically, a steep, coring-induced overprint is removed at low temperatures. Many samples were unstably magnetized and displayed erratic behavior during demagnetization (Sample 160-966D-3H-2, $80 \mathrm{~cm}$ ). Demagnetization steps $\left(\right.$ in ${ }^{\circ} \mathrm{C}$ ) are indicated on the figure. Symbols are as in Figure 2.
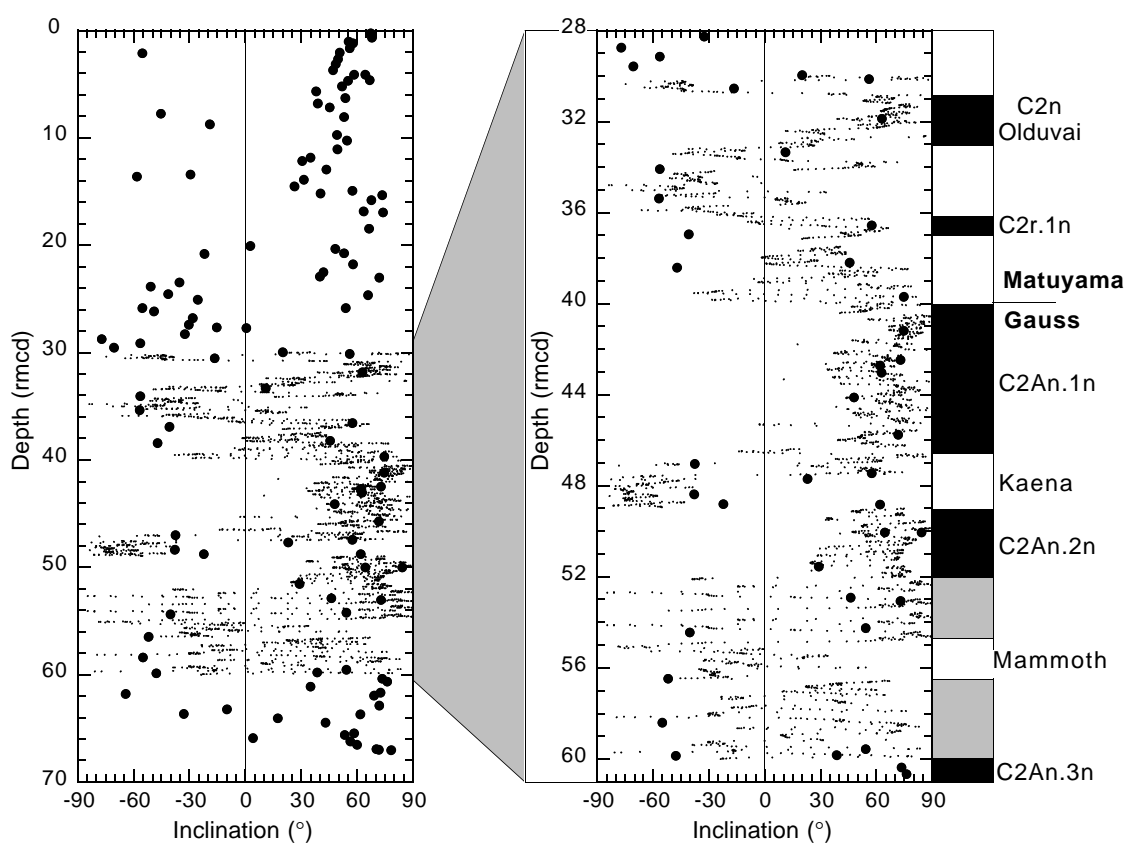

Figure 10. Magnetostratigraphic interpretation of the interval between 28 and $61 \mathrm{rmcd}$ at Site 966. Large solid circles represent results from thermal demagnetization of discrete samples (stably magnetized samples without significant overprint only), and small dots represent results from U-channel samples after demagnetization at $50 \mathrm{mT}$. A magnetostratigraphic interpretation is not possible above $28 \mathrm{rmcd}$ or below $61 \mathrm{rmcd}$. 
can be a direct consequence of major changes in remanence intensity over restricted stratigraphic intervals (associated with sapropels; Roberts et al., in press), which is an artifact of the pass-through measurement technique (Weeks et al., 1993; Roberts et al., 1996). Longcore data from intervals with such large changes in remanence intensity should therefore be treated with caution.

Considering the relatively poor quality of the paleomagnetic data, magnetostratigraphic results from Site 966 should be treated with caution. They do not provide a solid age framework, however, they provide useful independent support for the biostratigraphic data (Fig. 11).

\section{Site 967}

Site 967 (Fig. 1) is located near the foot of the northern slope of the Eratosthenes Seamount (Limonov et al., 1994) on the northern flank of a small (about $300 \mathrm{~m}$ high) northeast-southwest-trending ridge, at a water depth of $2554 \mathrm{~m}$ (Emeis, Robertson, Richter, et al., 1996). The site is part of a transect of holes that were cored from the top of Eratosthenes Seamount to the Cyprus margin to test the hypothesis that the seamount is undergoing collision with Cyprus and is breaking up during thrusting beneath Cyprus (Robertson et al., 1994; 1995). Seismic data and a gravity core taken by $R V$ Gelendzhik indicated the presence of a relatively expanded Pliocene to Pleistocene sedimentary sequence with potential for high-resolution studies of the Pliocene-Pleistocene sedimentary record of sapropel formation.

Discrete paleomagnetic samples were taken from the $120 \mathrm{~m}$ composite sequence of Holes 967A, 967B, 967C, and 967D. Sampling of U-channels was conducted in the uppermost $60 \mathrm{mcd}$, which represents a time interval of about 2 m.y. The sediments in this lithostratigraphic unit are dominated by brown and light gray bioturbated nannofossil ooze and nannofossil clay that is intercalated with numerous sapropels and turbidites. Sedimentation rates vary from 28.3 to 57.5 $\mathrm{m} / \mathrm{m}$.y. throughout the sampled sequence (Emeis, Robertson, Richter, et al., 1996).

\section{Paleomagnetic Results}

A total of 308 discrete samples from Holes 967A through 967D were subjected to stepwise thermal demagnetization. Of these, only 124 were ranked in category " $\mathrm{A}$ " and were obviously not remagnetized (Table 1).

Thermal demagnetization data provide useful information concerning the primary magnetic carriers in these sediments. Most samples displayed a noticeable drop in intensity between $250^{\circ} \mathrm{C}$ and $330^{\circ} \mathrm{C}$ (Fig. 12A), which may indicate the presence of ferrimagnetic

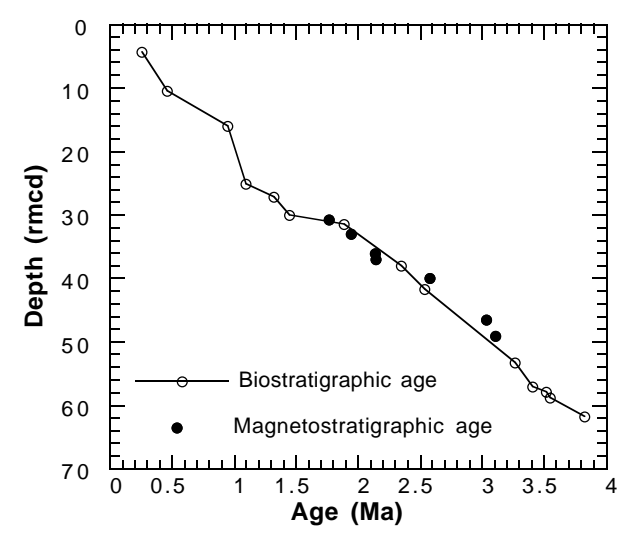

Figure 11. Comparison between biostratigraphic age determinations (Emeis, Robertson, Richter, et al., 1996) and magnetostratigraphic results from Site 966 (Fig. 10). iron sulfide minerals (e.g., Dekkers, 1989; Roberts, 1995). For many samples, remanence intensity decreases slightly near $550^{\circ} \mathrm{C}$ (Fig. $12 \mathrm{~A}$ ), with little remanent magnetization above $580^{\circ} \mathrm{C}$, which may indicate the presence of magnetite. Some intensity-decay curves indicate the persistence of a remanence to about $650^{\circ} \mathrm{C}$ (Fig. 12A). This is consistent with the presence of hematite, which has a Néel temperature of $675^{\circ} \mathrm{C}$ (Hunt et al., 1995).

Representative vector-demagnetization diagrams of normal and reversed polarity intervals are shown in Figure 13. The steep normal polarity overprint is usually removed at low temperatures, but occasionally heating at temperatures of $350^{\circ} \mathrm{C}$ is necessary before the characteristic remanence is isolated.

Remanence measurements were also made at 1-cm stratigraphic intervals after AF demagnetization of U-channel samples: this enabled assessment of demagnetization behavior at 5472 points down the composite sequence in the uppermost $60 \mathrm{~m}$ (Table 1). U-channel measurements appear to be of better quality than discrete sample measurements (Table 1), which demonstrates that coring-induced remagnetizations are more pronounced in the deeper sediments recovered from Site 967. During AF demagnetization, half of the NRM intensity was removed by $\sim 40 \mathrm{mT}$ (Fig. 12B) for most of the sediments. The distribution of the median destructive field (MDF), which is an estimate of the ease of AF demagnetization, is shown in Figure 14. A total of 168 samples (3\%) had MDFs $>70 \mathrm{mT}$ and were omitted from further analysis. MDF estimates range from 13.1 to $>70 \mathrm{mT}$, with a mean of $39.3 \mathrm{mT}(\mathrm{SD}=14.1 \mathrm{mT})$. This range of MDF values is consistent with the presence of either magnetite or a magnetic iron sulfide mineral as the main remanence carriers.

Representative vector-demagnetization diagrams for normal and reversed polarity portions of the U-channel samples (Fig. 15) indicate the presence of a well-defined, stable, characteristic remanence component for much of the studied interval. Much of the sediment is affected by a low-coercivity magnetic overprint that results from coring-induced effects or from viscous remanences that were probably
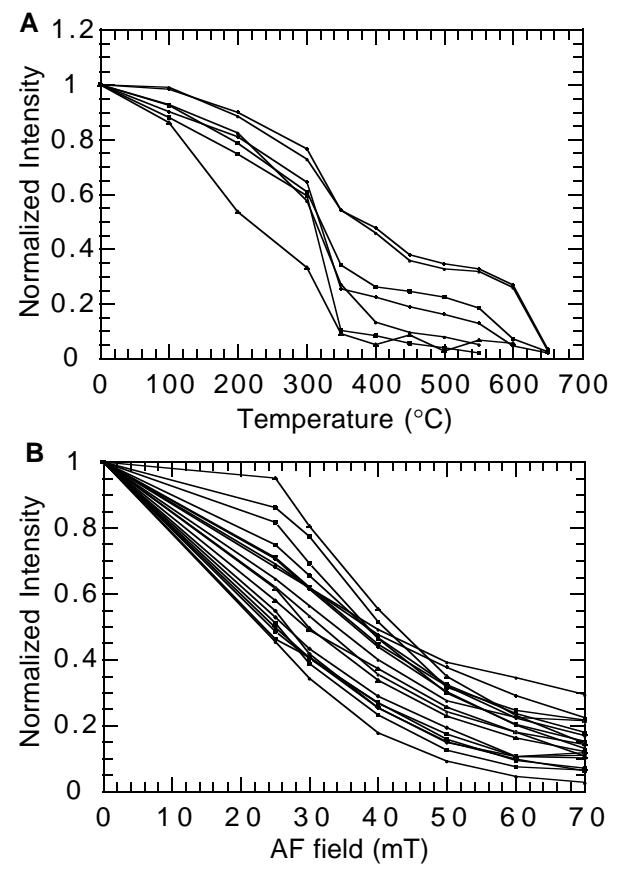

Figure 12. Unblocking temperature (A) and coercivity spectra (B) from discrete and U-channel samples, respectively, from Site 967 . The sharp decrease in intensity between $300^{\circ}$ and $350^{\circ} \mathrm{C}$ indicates the presence of a magnetic iron sulfide mineral. Magnetite and hematite contribute to a lesser degree (see text for discussion). 

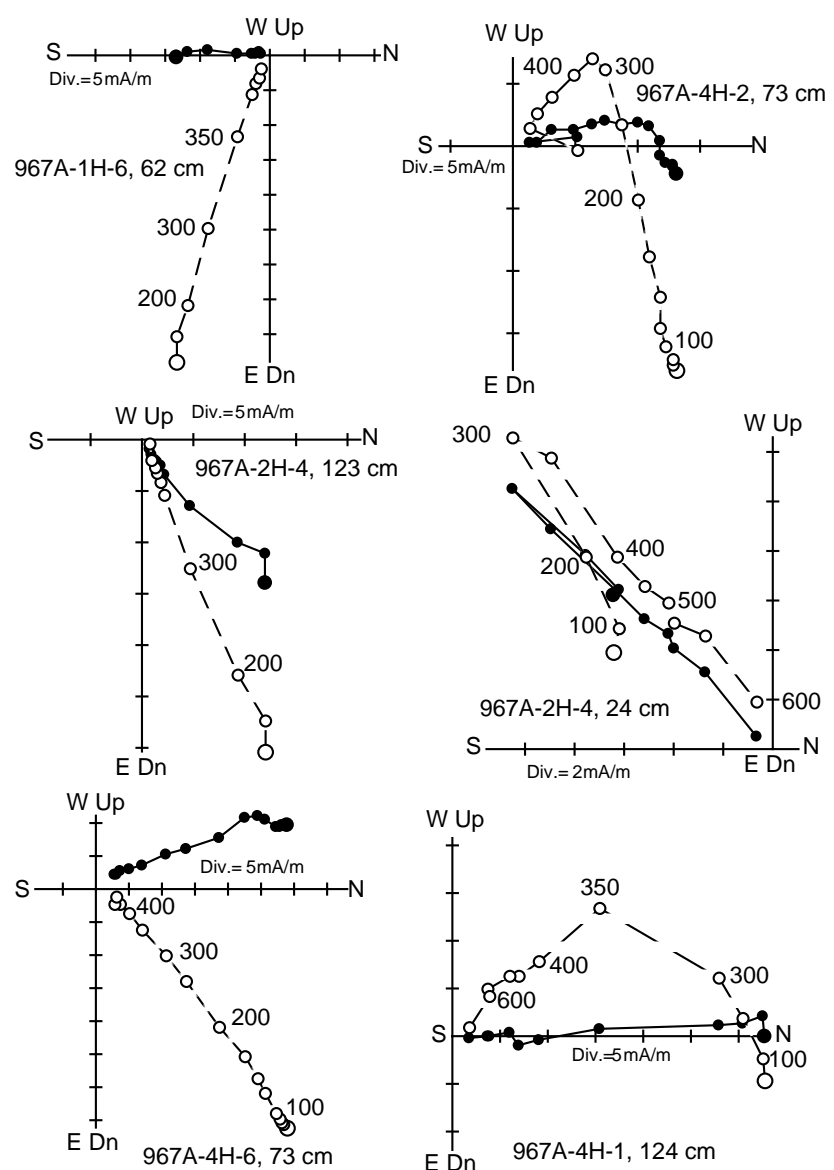

Figure 13. Vector-component diagrams for representative thermal demagnetization results for discrete samples from Site 967 . Reversed polarity samples (right) display a normal polarity overprint that is removed at $<350^{\circ} \mathrm{C}$. Many of the normal polarity samples (left) indicate the presence of a single, stable characteristic remanence component. Demagnetization steps (in ${ }^{\circ} \mathrm{C}$ ) are indicated on the figure. Symbols are as in Figure 2.

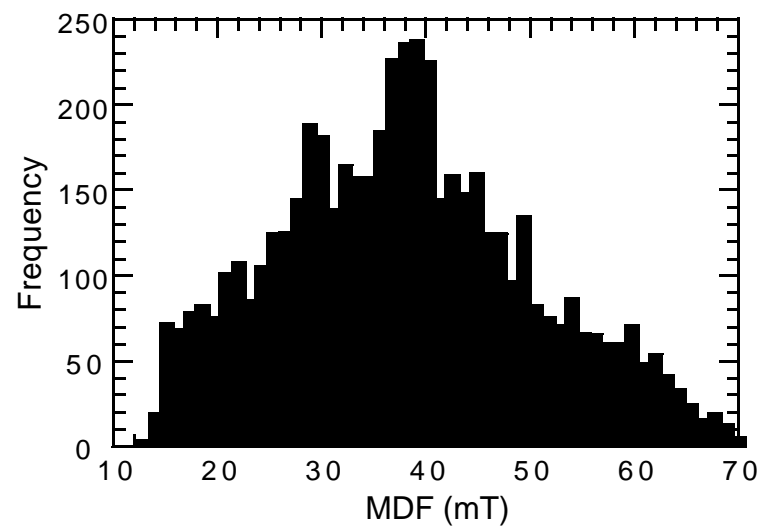

Figure 14. Histogram of the median destructive field (MDF) values for about 5500 U-channel measurements at Site 967. When 168 samples (3\%) with a MDF of $>70 \mathrm{mT}$ are omitted, the mean is $39.3 \mathrm{mT}$, which is consistent with the presence of magnetite and/or a magnetic iron sulfide mineral as the main remanence carrier.
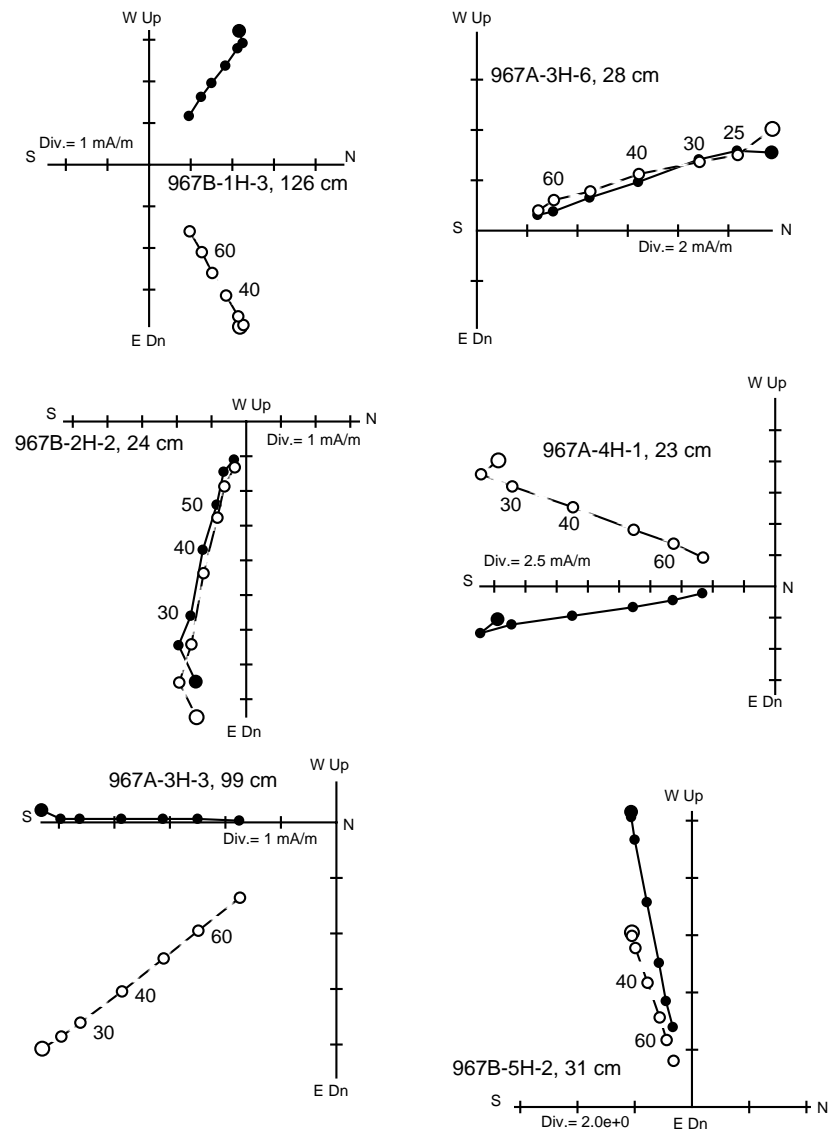

Figure 15. Vector-component diagrams for representative U-channel measurements (after AF demagnetization) with normal (left) and reversed (right) polarity at Site 967. Samples had been demagnetized in $25 \mathrm{mT}$ fields during shipboard analysis, after which a single, predominantly stable, remanence component remained.

acquired after coring. This overprint was typically removed in AFs of 25-30 mT. Paleomagnetic inclinations (after demagnetization at 60 $\mathrm{mT}$ ) have a bimodal distribution with maxima at $41^{\circ}$ (present-day value $=49^{\circ}$ ) and $-34^{\circ}$ (Fig. 16). The majority of the samples carry a normal polarity magnetization, and about one third (30.0\%) display reversed polarity.

\section{Magnetostratigraphic Interpretation}

Lower quality data (categories "B," "C," and obviously remagnetized samples) were not included in the final magnetostratigraphic interpretation (Fig. 17). Scattering of paleomagnetic inclinations between 40 and 55 rmcd (Fig. 18; unlike Fig. 17, this figure contains data with inclinations $>75^{\circ}$ ) is caused by an alternation of highly magnetic sapropel layers with weakly magnetized background sediment (Roberts et al., in press), and the directional artifacts that are produced when such extreme differences in remanence intensity are convolved with the response function of the pass-through magnetometer (Weeks et al., 1993; Roberts et al., 1996). The presence of such artifacts precludes meaningful magnetostratigraphic interpretation in this interval. The sapropels display reversed polarity, as expected in the Matuyama Chron, whereas the surrounding sediments display normal polarity. Steep, predominantly normal-polarity, inclinations in a sequence that most likely belongs to the Matuyama Chron are 


\section{RICHTER ET AL.}

probably caused by a coring-induced overprint that prohibits magnetostratigraphic interpretation between 60 and $120 \mathrm{mcd}$ (Fig. 17).

The Matuyama/Brunhes boundary appears to lie at about 30.6 mcd and the top of the Jaramillo subchron is interpreted to lie at 35.22 rmcd (Table 2). Two zones of reverse polarity are apparent within the Brunhes Chron at 2.26-5.78 rmcd ("Event A") and 12.45-14.76 rmcd ("Event B"). Both events occur within single cores: "Event A" occurs in Core 160-967B-1H and "Event B" occurs in Core 160-

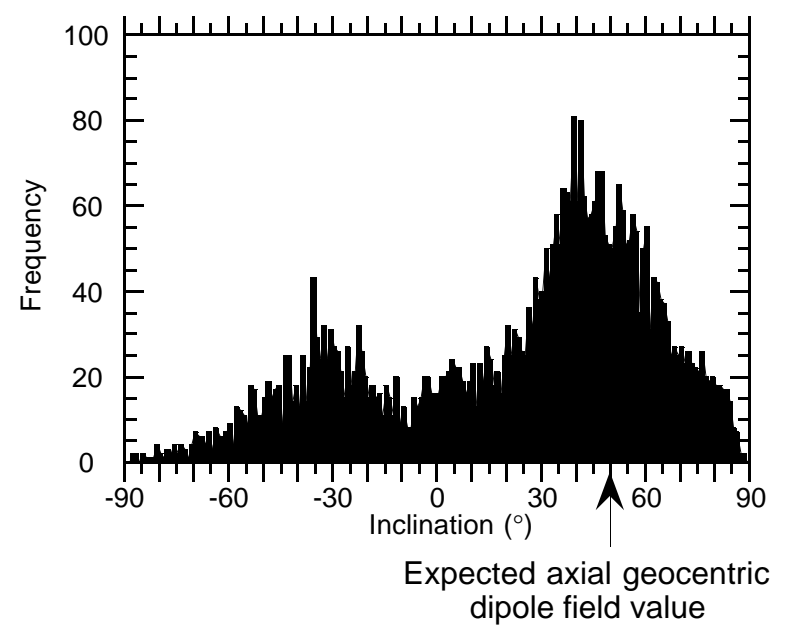

Figure 16. Histogram of paleomagnetic inclination values of $5500 \mathrm{U}$-channel measurements after demagnetization at $60 \mathrm{mT}$. The distribution is bimodal, with the maximum value close to that expected for an axial geocentric dipole field.

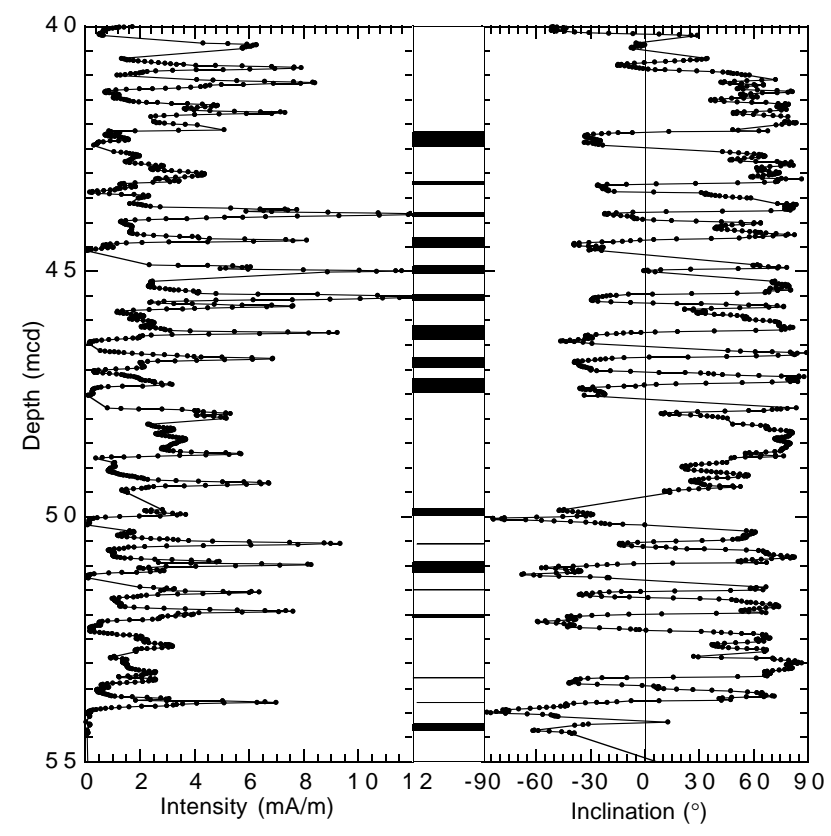

Figure 18. NRM intensity (left) and paleomagnetic inclination of U-channel samples (after AF demagnetization at $50 \mathrm{mT}$ ) compared to the occurrence of sapropel layers (black stripes) between 40 and $55 \mathrm{mcd}$ at Site 967. Both magnetic parameters are clearly related to the occurrence of sapropel layers. Magnetic polarity is reversed in the sapropel layers, but is normal in the background sediment. Biostratigraphic data indicate that these sediments (40-55 mcd) were deposited during the Matuyama Chron.
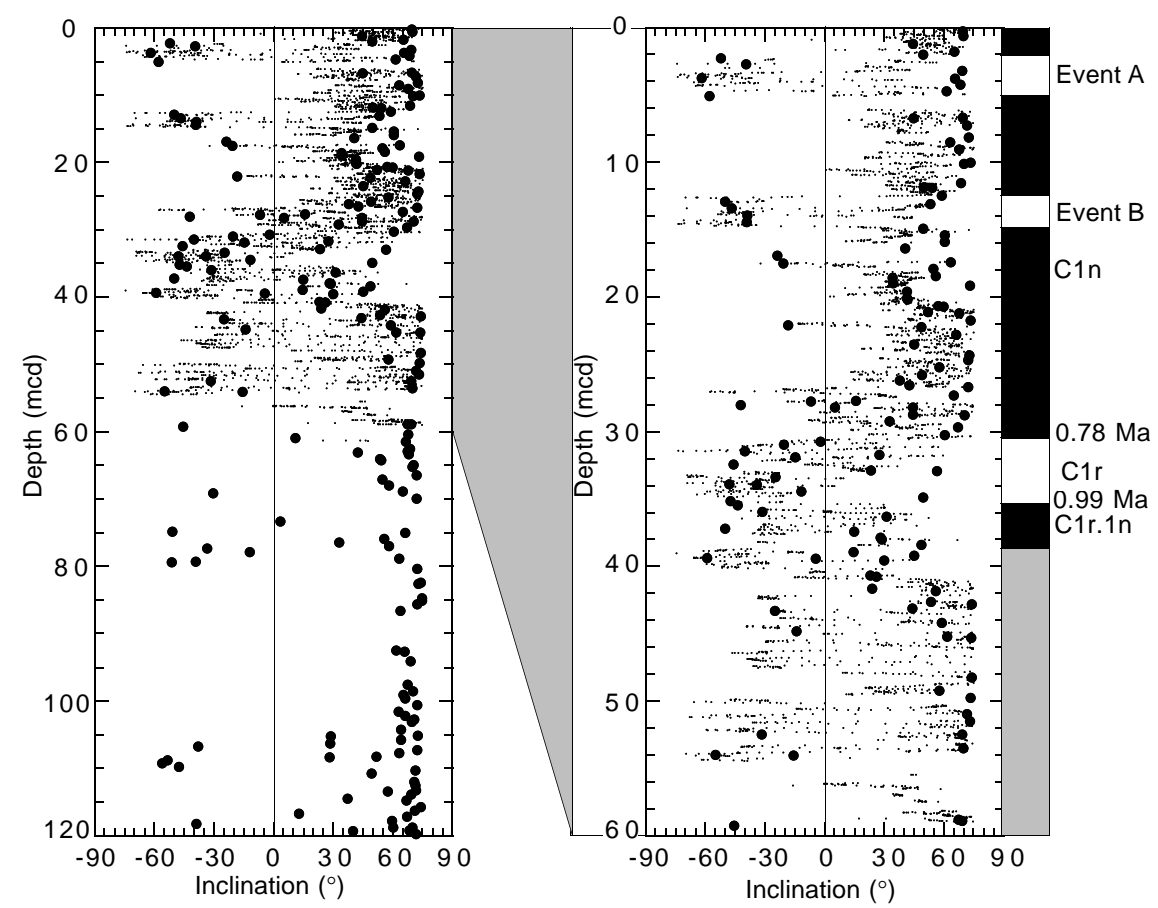

Figure 17. Magnetostratigraphic interpretation of the interval between 0 and $60 \mathrm{mcd}$ at Site 967 . Large solid circles represent results from thermal demagnetization of discrete samples (stably magnetized samples without significant overprint only), and small dots represent results from U-channel samples after demagnetization at $50 \mathrm{mT}$. Lithological variations dominate the magnetic properties between 40 and 55 mcd (Fig. 18) and prohibit magnetostratigraphic interpretation in this interval. Two zones of reversed polarity in the Brunhes Chron (labeled "Event A" and "Event B") occur in a time window similar to geomagnetic excursions that were reported from other localities (Langereis et al., 1997), but the possibility of a diagenetic origin cannot be excluded. 
967A-2H. Both events were also apparent during shipboard analysis of Holes 967A, 967B, and 967C (Emeis, Robertson, Richter, et al., 1996). Given the importance of diagenesis, particularly dissolution and precipitation of secondary magnetic phases, in determining the magnetization of sapropel-bearing sediments (e.g., Dekkers et al., 1994; Langereis et al., 1997; Roberts et al., in press), care should be taken in attributing zones of anomalous magnetization to be accurate reflections of geomagnetic field behavior. We have no independent evidence to support the interpretation that the two zones of anomalous magnetization recorded at Site 967 are caused by geomagnetic excursions, but the following discussion is based on this possibility.

Precise age constraints for "Event A" and "Event B" are presently scarce, but this should be aided by stable isotope and detailed paleontological data that will soon be available for this site. The first occurrence of E. huxleyi at $9.03 \mathrm{mcd}(0.26 \mathrm{Ma})$ and the last occurrence of $P$. lacunosa at $19.49 \mathrm{mcd}(0.44 \mathrm{Ma})$ are the only biostratigraphic datums that are available for preliminary age assessment. By applying a linear interpolation, "Event A" is estimated to have occurred between 63 and $137 \mathrm{ka}$, and "Event B" is estimated to have occurred between 327 and $369 \mathrm{ka}$. Several well-documented geomagnetic excursions were reported for the interval of time around "Event A." Tucholka et al. (1987), Channell et al. (1990), Channell and Torii (1990), and Tric et al. (1991) reported a geomagnetic event in several piston cores in the Eastern Mediterranean Sea and in the Tyrrhenian Sea (from oxygen isotope Stage 5), which they correlate to the Blake Event and age-equivalent events of the Atlantic, the Caribbean (Smith and Foster, 1969; Denham, 1976; Denham et al., 1977), southern Italy (Creer et al., 1980), Japan (Nakajima and Miura, 1982) and the Chinese Loess Plateau (Zhu et al. 1994). Age determinations for the Blake Event range from 100 to $120 \mathrm{ka}$, and estimates for the duration of the Blake Event range from 5 to 50 k.y. (Creer et al., 1980; Tucholka et al., 1987; Denham et al., 1977). A duration near the lower range of estimates is more likely given the observation that many records do not contain evidence of the Blake Event. Langereis et al. (1997) attributed the lack of evidence for the Blake Event in a core from the Calabrian Ridge (near Site 964) to the effects of diagenetic remobilization of magnetic minerals between Sapropels S4 and S5. Dekkers et al. (1994) and Langereis et al. (1997) also identified an excursion from a core on the Calabrian Ridge at about 315-325 $\mathrm{ka}$. If the zone of anomalous magnetization, which is estimated to have been deposited between 327 and $369 \mathrm{ka}$ at Site 967 , is a genuine geomagnetic excursion, it is possible that it is a correlative of the $\mathrm{Ca}$ labrian Ridge excursion identified by Langereis et al. (1997), given the uncertainty in our age estimate for this feature.

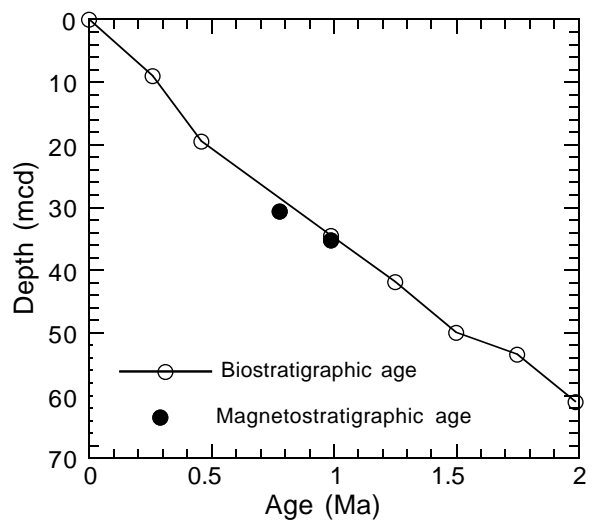

Figure 19. Comparison between biostratigraphic age determinations (Emeis, Robertson, Richter, et al., 1996) and magnetostratigraphic results from Site 967 (Fig. 17). The magnetostratigraphic interpretation provides useful support for the biostratigraphic interpretation.
The positions of the above-outlined magnetic polarity boundaries are summarized in Table 2 and agree well with the calcareous nannofossil stratigraphy (Fig. 19).

\section{Site 968}

Site 968 lies 13 nmi north of Site 967 in water depths of $1960 \mathrm{~m}$, on the lower slope of the Cyprus margin (Fig. 1). The dominant lithology is clayey nannofossil ooze with up to $50 \%$ calcium carbonate; more than 80 discrete sapropel layers were documented at Site 968. A total of 54 samples from Hole 968A were thermally demagnetized. Of these, only seven samples were classified in category "A" (Table 1). This poor result precluded any paleomagnetic and magnetostratigraphic interpretation.

\section{Site 969}

Site 969 is located on the Mediterranean Ridge, 100 km south of Crete (Fig. 1), in water depths of $2200 \mathrm{~m}$. The sediment is dominated by nannofossil ooze with numerous sapropel layers and four red intervals from which traces of hematite were identified by sediment smear-slide observations. Promising shipboard paleomagnetic results (Emeis, Robertson, Richter, et al., 1996) led to demagnetization of 239 discrete samples (165 thermal, $74 \mathrm{AF}$ ) in our shore-based work. In addition, we stepwise demagnetized U-channel samples from Cores 160-969B-5H and 6H (35.01-55.09 mcd). About half of the discrete samples were classified in category "A" (Table 1). The paleomagnetic inclinations from the discrete and U-channel samples correlate reasonably well, although they display a mostly erratic behavior (Fig. 20) that did not yield a clear magnetic polarity stratigraphy.

\section{Site 972}

Site 972 lies near the outer deformation front of the westernmost part of the Mediterranean Ridge accretionary complex (Fig. 1), in more than $4000 \mathrm{~m}$ of water. Sediments of latest Pliocene to Holocene age (with many turbidites) were recovered from a single hole at Site 972, which penetrated to 95.4 mbsf. The sediments are dominated by nannofossil clay, clayey nannofossil ooze, and nannofossil ooze, with more than two dozen sapropel bands being present.

A total of 109 discrete samples from Site 972 were subjected to stepwise demagnetization (Table 1). The paleomagnetic record determined from Site 972 is dominated by normal polarity (Fig. 20). Paleontological data indicate that the bottom of the measured sequence is associated with the first occurrence of Gephyrocapsa sp. 3 (Emeis, Robertson, Richter, et al., 1996), which is dated at about $0.99 \mathrm{Ma}$ (Sprovieri, 1993). This suggests that the Matuyama/Brunhes boundary and the Jaramillo subchron should be preserved in the record. The absence of any indication of these polarity zones in the paleomagnetic record prevents any meaningful interpretation from being made. Numerous turbidites occur in this sequence, and erosion associated with these deposits may partially account for the difficulty in establishing a paleomagnetic chronology.

\section{Site 973}

Site 973 lies near Site 972, higher up the Mediterranean Ridge accretionary complex (Fig. 1), at a water depth of more than $3800 \mathrm{~m}$. Five holes were cored at this site (Holes 973A-973E), which provided sufficient stratigraphic overlap to allow a composite section to be derived to about 65 mcd (Emeis, Robertson, Richter et al., 1996). Hole 973A was the deepest hole cored (148.5 mbsf). Because of the limited stratigraphic value of this site, resulting from the large number of turbidites within the sequence, paleomagnetic sampling was restricted to Hole 973A. 
Figure 20. Magnetic inclination vs. depth for samples from Sites 969, 972, and 973. No magnetostratigraphic interpretation can be made for any of these sites. Gray lines at Site 969 represent results from Uchannel measurements.
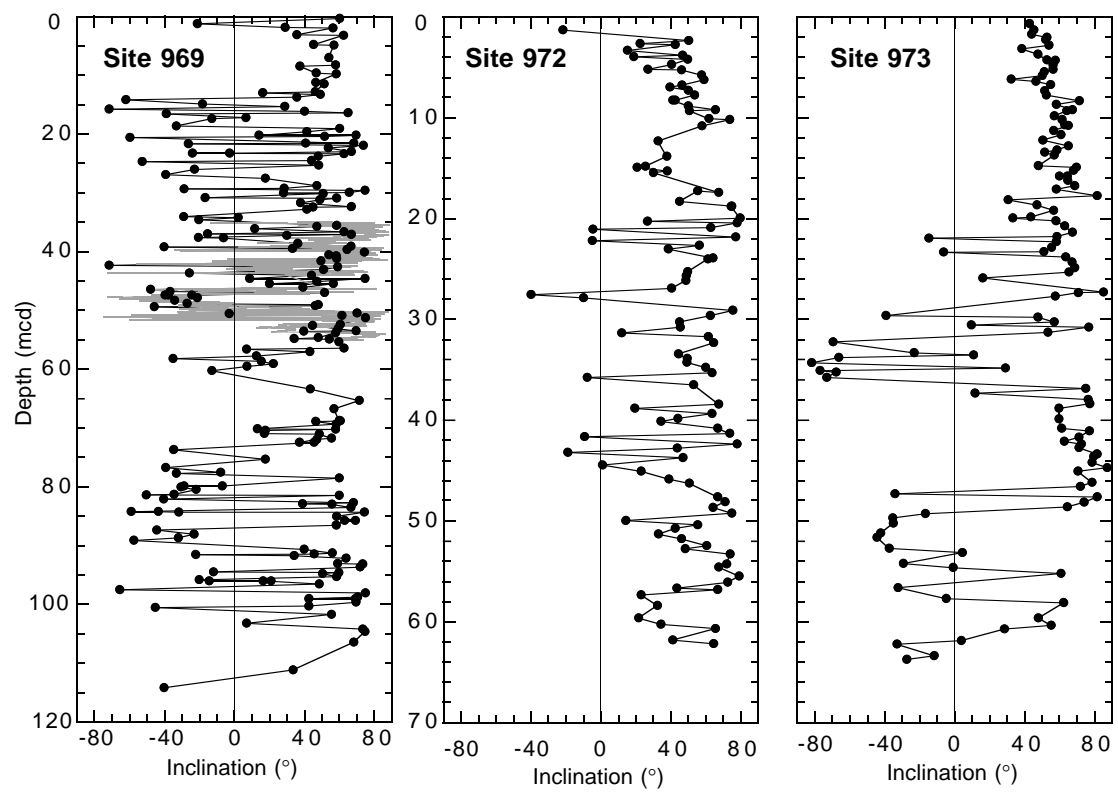

A total of 126 discrete samples from Site 973 was subjected to stepwise demagnetization (Table 1). Biostratigraphic data from Site 973 (Emeis, Robertson, Richter, et al., 1996) indicate that sediments from the base of the recovered sequence in Hole 973A represent the lowermost Pleistocene, near the first occurrence of large $(>5.5 \mu \mathrm{m})$ Gephyrocapsa, which is dated at about $1.5 \mathrm{Ma}$ in the Mediterranean (Sprovieri, 1993). This suggests that the Matuyama/Brunhes transition and the Jaramillo subchron should be preserved in the record. The zone of reversed magnetization at around 30-37 mbsf (Fig. 20) falls within the depth range in which the Matuyama/Brunhes transition is expected, but the paleomagnetic record shown in Figure 20 does not permit determination of an unambiguous polarity stratigraphy at Site 973.

\section{DISCUSSION AND CONCLUSIONS}

The magnetostratigraphies acquired from Leg 160 sediments are generally of poor quality because of several factors, including persistent magnetic overprinting because of coring-related effects, diagenetic dissolution of detrital magnetic minerals and authigenic precipitation of secondary magnetic minerals, and a strong correlation between lithology and magnetic inclination. By applying a rigorous quality control on our large data set, we were able, despite these problems, to obtain reliable magnetostratigraphic interpretations at Sites 963, 966, and 967. At the westernmost location (Site 963), we identified chronozones C1n (Brunhes Chron) through C1r.2r-1n (Cobb Mountain cryptochron), which dates back to $1.2 \mathrm{Ma}$. A relatively condensed sequence, with low sedimentation rates, was recovered from Site 966. The magnetostratigraphic record from Site 966 extends from the termination of the Mammoth subchron (3.22 Ma) to the termination of the Olduvai subchron at $1.77 \mathrm{Ma}$ before an unstable magnetization obscures the record. At Site 967, which is near Site 966, Chrons C1n (Brunhes) and the termination of the Jaramillo subchron $(0.99 \mathrm{Ma})$ can be identified in the top $35 \mathrm{~m}$ of the sediment column. Below the Jaramillo subchron, the frequency of dark, organicrich, sapropel layers increases dramatically and reveals a close correlation not only between magnetic intensity, but also between paleomagnetic inclination and the occurrence of sapropel layers (in Uchannel measurements). The unusual magnetic properties of the sapropel layers and their relation to the background sediment is described more fully by Roberts et al. (in press). The combination of discrete samples and U-channel samples enabled elucidation of the otherwise ambiguous record from Sites 966 and 967. Sedimentation rates are sufficiently high to allow the tentative identification of two geomagnetic "events" in the Brunhes Chron at Site 967. "Event A" is identical in age to the Blake Event and an age-equivalent zone to "Event B" has been described from the Calabrian Ridge. Care should be taken, however, in interpreting these zones of anomalous magnetization as possible geomagnetic excursions, given the effects of diagenesis on the magnetic record at these sites.

\section{ACKNOWLEDGMENTS}

This research was supported in part by grants from the JOIDES U.S. Science Support Advisory Committee (USSSAC) to C. Richter, A.P. Roberts, and J.S. Stoner. We thank Ken Verosub and Akira Hayashida for their generous assistance and for access to the facilities at the UCD paleomagnetic laboratory, and especially Akira Hayashida for his hospitality and patience during the visits of C. Richter and J.S. Stoner to UCD. We are grateful to all members of the Leg 160 Shipboard Scientific Party for numerous discussions. Shipboard scientists E. Di Stefano, M. Howell, S. Spezzaferri, and T.S. Staerker contributed biostratigraphic data. We also acknowledge the highly professional support of the ODP technicians and the drill crew of the JOIDES Resolution during Leg 160, without whom this work would not have been possible. C. Kissel, C.G. Langereis, and J.-P. Valet provided insightful reviews that improved the manuscript.

\section{REFERENCES}

Albianelli, A., Napoleone, G., and Pompeo, R., 1993. Il ruolo dei solfuri nella magnetizzazione residua di sedimenti marini e lacustri Plio-Quaternari. Proc. 12th Conv., Consig. Naz. Richerche Gruppo Naz. Geofis. Terra Solida, 2:873-884.

Berger, A.L., and Loutre, M.F., 1991. Isolation values for the climate of the last 10 million years. Quat. Sci. Rev., 10:297-317.

Blechschmidt, G., Cita, M.B., Mazzei, R., and Salvatori, G. 1982. Stratigraphy of the Western Mediterranean and Southern Calabrian Ridges, Eastern Mediterranean. Mar. Micropaleontol., 7:101-134.

Bracci, G., Dalena, D., and Orlandi, P., 1985. La greigite di Mentana, Lazio. Rend. Soc. Ital. Mineral. Petrol., 40:295-298.

Calvert, S.E., 1983. Geochemistry of Pleistocene sapropels and associated sediments from the Eastern Mediterranean. Oceanol. Acta, 6:225-267.

Cande, S.C., and Kent, D.V., 1995. Revised calibration of the geomagnetic polarity timescale for the Late Cretaceous and Cenozoic. J. Geophys. Res., 100:6093-6095. 
Canfield, D.E., and Berner, R.A., 1987. Dissolution and pyritization of magnetite in anoxic marine sediments. Geochim. Cosmochim. Acta, 51:645659

Channell, J.E.T., and Hawthorne, T., 1990. Progressive dissolution of titanomagnetites at ODP Site 653 (Tyrrhenian Sea). Earth Planet. Sci. Lett., 96:469-480.

Channell, J.E.T., and Torii, M., 1990. Two "events" recorded in the Brunhes Chron at Hole 650A (ODP Leg 107, Tyrrhenian Sea): geomagnetic phenomena? In Kastens, K.A., Mascle, J., et al., Proc. ODP, Sci. Results, 107: College Station, TX (Ocean Drilling Program), 347-359.

Channell, J.E.T., Torii, M., and Hawthorne, T., 1990. Magnetostratigraphy of sediments recovered at Sites 650, 651, 652, and 654 (Leg 107, Tyrrhenian Sea). In Kastens, K.A., Mascle, J., et al., Proc. ODP, Sci. Results, 107: College Station, TX (Ocean Drilling Program), 335-346.

Comas, M.C., Zahn, R., Klaus, A., et al., 1996. Proc. ODP, Init. Repts., 161: College Station, TX (Ocean Drilling Program).

Creer, K.M., Readman, P.W., and Jacobs, A.M., 1980. Palaeomagnetic and palaeontological dating of a section at Giolia Tauro, Italy: identification of the Blake event. Earth Planet. Sci. Lett., 50:289-300.

Dekkers, M.J., 1989. Magnetic properties of natural pyrrhotite, II. High- and low-temperature behaviour of Jrs and TRM as function of grain size. Phys. Earth Planet. Inter., 57:266-283.

Dekkers, M.J., Langereis, C.G., Vriend, S.P., van Santvoort, P.J.M., and De Lange, G.J., 1994. Fuzzy $c$-means cluster analysis of early diagenetic effects on natural remanent magnetization acquisition in a 1.1 Myr piston core from the Central Mediterranean. Phys. Earth Planet. Inter, 85:155171.

Denham, C.R., 1976. Blake polarity episode in two cores from the Greater Antilles outer ridge. Earth Planet. Sci. Lett., 29:422-434.

Denham, C.R., Anderson, R.F., and Bacon, M.P., 1977. Paleomagnetism and radiochemical age estimates for Late Brunhes polarity episodes. Earth Planet. Sci. Lett., 35:384-397.

Emeis, K.-C., Robertson, A.H.F., Richter, C., et al., 1996. Proc. ODP, Init. Repts., 160: College Station, TX (Ocean Drilling Program).

Finetti, I., 1982. Structure, stratigraphy and evolution of central Mediterranean. Boll. Geofis. Teor. Appl., 24:247-315.

Florindo, F., and Sagnotti, L., 1995. Palaeomagnetism and rock magnetism at the upper Pliocene Valle Ricca (Rome, Italy) section. Geophys. J. Int., 123:340-354.

Garavelli, C.L., and Nuovo, G., 1971. La greigite delle argille di Montemesola. Period. Mineral., 40:305-327.

Hagelberg, T., Shackleton, N., Pisias, N., and Shipboard Scientific Party, 1992. Development of composite depth sections for Sites 844 through 854. In Mayer, L., Pisias, N., Janecek, T., et al., Proc. ODP, Init. Repts., 138 (Pt. 1): College Station, TX (Ocean Drilling Program), 79-85.

Hilgen, F.J., 1987. Sedimentary rhythms and high-resolution chronostratigraphic correlations in the Mediterranean Pliocene. Newsl. Stratigr., 17:109-127.

, 1991a. Astronomical calibration of Gauss to Matuyama sapropels in the Mediterranean and implication for the geomagnetic polarity time scale. Earth Planet. Sci. Lett., 104:226-244.

1991b. Extension of the astronomically calibrated (polarity) time scale to the Miocene/Pliocene boundary. Earth Planet. Sci. Lett., 107:349-368

Hilgen, F.J., Lourens, L.J., Berger, A., and Loutre, M.F., 1993. Evaluation of the astronomically calibrated time-scale for the late Pliocene and earliest Pleistocene. Paleoceanography, 8:549-565.

Hunt, C., Moskowitz, B.M., and Banerjee, S.K., 1995. Magnetic properties of rocks and minerals. In Rock Physics and Phase Relations. AGU Ref. Shelf 3, 189-204.

Karlin, R., and Levi, S., 1983. Diagenesis of magnetic minerals in recent hemipelagic sediments. Nature, 303:327-330.

-1985. Geochemical and sedimentological control of the magnetic properties of hemipelagic sediments. J. Geophys. Res., 90:10373-10392.

Kastens, K.A., Mascle, J., et al., 1990. Proc. ODP, Sci. Results, 107: College Station, TX (Ocean Drilling Program).

Klinkhammer, G.P., and Lambert, C.E., 1989. Preservation of organic matter during salinity excursions. Nature, 339:271-274.

Langereis, C.G., Dekkers, M.J., van Santvoort, P.J.M., and de Lange, G.J., 1997. Magnetostratigraphy and astronomical calibration of the last 1.1 Myr from a Central Mediterranean piston core and dating of short events in the Brunhes. Geophys. J. Int., 129:75-94.

Langereis, C.G., and Hilgen, F.J., 1991. The Rosello composite: a Mediterranean and global reference section for the early to early-late Pliocene. Earth Planet. Sci. Lett., 104:211-225.
Limonov, A.F., Woodside, J.M., and Ivanov, M.K. (Eds.), 1994. Mud Volcanism in the Mediterranean and Black Seas and Shallow Structure of the Eratosthenes Seamount. Initial Results of the Geological and Geophysical Investigations during the Third "Training-through-Research" Cruise of the R/V Gelendzhik (June-July 1993). UNESCO Rep. Mar. Sci., 64.

Lourens, L.J., Antonarakou, A., Hilgen, F.J., Van Hoof, A.A.M., VergnaudGrazzini, C., and Zachariasse, W.J., 1996. Evaluation of the Plio-Pleistocene astronomical timescale. Paleoceanography, 11:391-413.

Mattei, M., Kissel, C., and Funiciello, R., 1996. No tectonic rotation of the Tuscan Tyrrhenian margin (Italy) since late Messinian. J. Geophys. Res., 101:2835-2845.

Nakajima, T., and Miura, S., 1982. Blake polarity event found in the Hamaji Volcanic Ash Layer in Fukui Prefecture. Quat. Res. (Tokyo), 22:97-101.

Paillard, D., 1996. Macintosh program performs time-series analysis. Eos, 77:379.

Roberts, A.P., 1995. Magnetic properties of sedimentary greigite $\left(\mathrm{Fe}_{3} \mathrm{~S}_{4}\right)$. Earth Planet. Sci. Lett., 134:227-236.

Roberts, A.P., Stoner, J.S., and Richter, C., 1996. Coring induced magnetic overprints and limitations of the long-core paleomagnetic measurements technique: some observations from Leg 160, eastern Mediterranean Sea. In Emeis, K.-C., Robertson, A.H.F., Richter, C., et al., Proc. ODP, Init. Repts., 160: College Station, TX (Ocean Drilling Program), 497-505.

, in press. Diagenetic magnetic enhancement of sapropels from the eastern Mediterranean Sea. Mar. Geol.

Robertson, A.H.F., Kidd, R.B., Ivanov, M.K., Limonov, A.F., Woodside, J.M., Galindo-Zaldivar, J., and Nieto, L., 1994. Probing continental collision in the Mediterranean Sea. Eos, 75:233.

, 1995. Eratosthenes Seamount, easternmost Mediterranean: evidence of active collapse and underthrusting beneath the Cyprus active margin. Terra Nova, 7:254-264.

Rossignol-Strick, M., 1983. African monsoons: an immediate climate response to orbital insolation. Nature, 304:46-49.

Smith, J.D., and Foster, J.H., 1969. Geomagnetic reversal in Brunhes normal polarity epoch. Science, 163:565-567.

Sprovieri, R., 1993. Pliocene-early Pleistocene astronomically forced planktonic foraminifera abundance fluctuations and chronology of Mediterranean calcareous plankton bio-events. Riv. Ital. Paleontol. Stratigr, 99:371-414.

Sutherland, H.E., Calvert, S.E., and Morris, J.R., 1984. Geochemical studies of the recent sapropel and associated sediment from the Hellenic Outer Ridge, eastern Mediterranean Sea, I. Mineralogy and chemical composition. Mar. Geol., 56:79-92.

Tric, E., Laj, C., Valet, J.-P., Tucholka, P., Paterne, M., and Guichard, F., 1991. The Blake geomagnetic event: transition geometry, dynamical characteristics and geomagnetic significance. Earth Planet. Sci. Lett., 102:1-13.

Tucholka, P., Fontugue, M., Guichard, F., and Paterne, M., 1987. The Blake polarity episode in cores from the Mediterranean Sea. Earth Planet. Sci. Lett., 86:320-326.

Van Velzen, A.J., Dekkers, M.J., and Zijderveld, J.D.A., 1993. Magnetic iron-nickel sulphides in the Pliocene and Pleistocene marine marls from the Vrica section (Calabria, Italy). Earth Planet. Sci. Lett., 115:43-55.

Vergnaud-Grazzini, C., Ryan, W.B.F., and Cita, M.B., 1977. Stable isotope fractionation, climatic change and episodic stagnation in the Eastern Mediterranean during the Late Quaternary. Mar. Micropaleontol., 2:353370.

Weeks, R.J., Laj, C., Endignoux, L., Fuller, M.D., Roberts, A.P., Manganne, R., Blanchard, E., and Goree, W., 1993. Improvements in long-core measurement techniques: applications in palaeomagnetism and palaeoceanography. Geophys. J. Int., 114:651-662.

Zhu, R.X., Zhou, L.P., Laj, C., Mazaud, A., and Ding, Z.L., 1994. The Blake geomagnetic polarity episode recorded in Chinese loess. Geophys. Res. Lett., 21:697-700.

Date of initial receipt: 20 January 1997

Date of acceptance: 22 June 1997

Ms 160SR-051 